\title{
EL RÉGIMEN DE LOS CUMPLIMIENTOS DEFECTUOSOS EN LA COMPRAVENTA
}

\author{
DEFECTIVE PERFORMANCE IN THE SALE OF GOODS
}

\section{IÑigo de la Maza Gazmuri*}

RESUMEN: Los cumplimientos defectuosos constituyen uno de los temas más desafiantes en la regulación de la compraventa y, sin embargo, a la vez, se encuentran virtualmente inexplorados. Este trabajo intenta una primera exploración considerando múltiples ejemplos de supuestos de cumplimientos defectuosos.

Palabras clave: Incumplimiento contractual, cumplimiento defectuoso, compraventa, remedios.

ABSTRACT: Defective performances of contract are probably one of the most challenging issues in Chilean law of sales and yet remain virtually unexplored. This paper attempts to tackle the issue considering several cases of defective performance.

Key words: Breach of Contract, deffective performance, sales, remedies.

\section{INTRODUCCIÓN}

Ya sea por los problemas que presenta y la densidad dogmática de estos o por su enorme aplicación práctica, no existe un contrato más importante que la compraventa ${ }^{1}$. Sorprendentemente, en el ámbito nacional, la atención que le ha prestado la doctrina es particularmente escasa. No hay mayor exageración si se afirma que desde 1916 el único texto monográfico importante publicado es la tesis de grado de Arturo Alessandri Rodríguez ${ }^{2}$.

Esta situación, de por sí inquietante, se torna más urgente si se consideran los enormes cambios que ha experimentado la comprensión dogmática de la compraventa desde la Convención de Viena sobre Compraventa Internacional de Mercaderías ${ }^{3}$.

Conviene entonces avanzar, aunque sea modestamente.

El tema que desarrollo en las páginas siguientes se enmarca dentro de las obligaciones del vendedor, en particular a su incumplimiento y la protección que le prodiga el Código Civil al comprador frente a él.

\footnotetext{
Profesor Investigador Facultad de Derecho de la Universidad Diego Portales; Profesor de Derecho Civil; Abogado; Doctor en Derecho. Correo electrónico: inigo.delamaza@udp.cl. Este artículo se enmarca en el Proyecto Fondecyt regular no 1120548 . El tratamiento de las entregas defectuosas en el derecho chileno: hacia una noción de incumplimiento amplia y unitaria.

1 A esto todavía podría sumarse que es el contrato sobre cuyo modelo se ha elaborado lo que, desde hace algún tiempo, suele denominarse el "nuevo derecho de las obligaciones. Respecto del nuevo derecho de las obligaciones la mejor introducción disponible, hasta donde llegan mis noticias, es Morales (2006).

2 Alessandri (1917).

3 Una buena aproximación en VIDAL (2006).
} 
En particular, me interesa lo que voy a denominar "cumplimientos defectuosos", aquellos en que ha existido una entrega -material y jurídica ${ }^{4}$, sin embargo, dicha entrega no resulta suficiente para satisfacer el interés del comprador protegido por el contrato.

¿Cómo se disciplinan esos incumplimientos en el Título XXIII del Libro IV del Código Civil ${ }^{5}$. O formulada la pregunta en otros términos ¿cómo protege la regulación de la compraventa al comprador frente a esta situación?

Como puede advertirse se trata de una pregunta extremadamente amplia cuya respuesta exige compromisos con la actividad de la doctrina y de los tribunales. Tratándose de la doctrina, la cuestión no resulta demasiado desafiante en el ámbito nacional. Como ya he dicho, el contrato de compraventa no ha inquietado especialmente a los autores nacionales. Con la actividad de los tribunales, sin embargo, la cuestión es distinta. Existe abundante material y mi pretensión no es -no puede ser en un trabajo como este- dar acabada cuenta de dicho material. Mi ánimo, más bien, consiste en servirme de las sentencias para ilustrar -no agotar monográficamente- el régimen de los cumplimientos defectuosos y advertir algunas de sus características que aconsejan su revisión. La modestia de esta proposición se encuentra justificada, en buena parte, porque se trata de un esfuerzo que no se ha hecho en Chile.

Procedo de la siguiente manera. En la primera parte del trabajo suministro algunas ideas respecto a la noción de incumplimiento, sus manifestaciones y las obligaciones del vendedor y los remedios frente a su incumplimiento. Según creo, esos materiales contribuirán a formar el marco conceptual con el que abordo la segunda parte de este trabajo.

En la segunda parte trato cinco supuestos de cumplimiento defectuoso: el aliud pro alio, los defectos de cabida, los vicios redhibitorios, la venta de cosa ajena y la evicción. El examen de estos supuestos debe permitir contestar dos preguntas cuyas respuestas, en mi opinión, configuran el régimen de los cumplimientos defectuosos. A saber: en cuál de las obligaciones del vendedor debe incardinarse su incumplimiento y, en segundo lugar, de qué remedios dispone el comprador frente a este tipo de incumplimientos. No me interesa examinar cuáles son los remedios individualmente considerados, sino más bien qué régimen de remedios es el que tutela la posición del comprador.

\section{2.}

En esta primera parte presento tres cuestiones que deberían resultar útiles para comprender el régimen de los cumplimientos defectuosos que trato en la segunda parte. La primera se refiere a la noción de incumplimiento contractual y consiste en una consideración pragmática: al margen de la amplitud de la noción su alcance, en verdad, depende del hecho que a ella se vincule alguna acción cuyo objetivo sea la protección del comprador. La segunda cuestión corresponde a las formas en que se manifiesta el incumplimiento. La

\footnotetext{
4 No considero supuestos en los que ha existido entrega material pero no jurídica o viceversa. La razón es que en dichos supuestos resulta evidente que se ha incumplido con la obligación de entrega y también resulta evidente que el comprador puede recurrir al régimen general de remedios. En cambio, en los supuestos que me interesa revisar en este trabajo ninguno de los dos puntos es tan evidente.

5 Por lo tanto, no voy a considerar el estado de la cuestión ni en el Código de Comercio ni en la Ley 19.496 sobre Protección de los Derechos de los Consumidores.
} 
tipología que me interesa considerar es aquella que distingue entre omisión de la prestación y prestación defectuosa. Finalmente, la tercera cuestión se relaciona con la forma en que se modula la obligación del vendedor en el derecho chileno (entrega y saneamiento) y los remedios de que dispone el comprador ${ }^{6}$.

\subsection{El INCUMPLIMIENTO CONTRACTUAL}

Al margen de las diferencias que resulta posible advertir entre las diversas definiciones de incumplimiento contractual, existe un mínimo común denominador en todas ellas. Como ha sugerido Carrasco Perera, se trata de un concepto negativo, es decir:

"Describe toda forma posible en la que el deudor deja de cumplir el deber contractual, mediante la no realización de la prestación debida o la realización de un modo distinto al debido, provocando insatisfacción del interés contractual del acreedor"”.

En el ámbito nacional la misma idea ha sido advertida por autores como Fernando Fueyo Laneri, refiriéndose a "la fórmula de la negación"8 o René Abeliuk Manasevich señalando que "no hay otra forma que la negativa para definir el incumplimiento: el no pago, esto es la falta de satisfacción íntegra y oportuna de la obligación al tenor de ella"’.

A idéntica conclusión, siempre en el ámbito nacional, puede llegarse a través de la lectura del Código Civil. Aun cuando este no disponga de una noción de incumplimiento, resulta posible advertir el carácter negativo de este vinculando las reglas del efecto de las obligaciones (en particular el artículo 1.556) o con las del pago (específicamente, las de los artículos 1.569 y 1.591$)^{10}$.

\footnotetext{
6 Aunque la expresión "remedio" carezca de arraigo en la tradición romano continental, existen buenas razones para servirse de ella. Como ha sugerido Morales Moreno (2011) p. 402. "El término remedio, no es un término que tenga arraigo histórico en nuestro ordenamiento ni en la tradición jurídica continental, proveniente del Derecho romano. En ella es más frecuente hablar de acciones, o de pretensiones, si nos situamos fuera del ámbito estrictamente procesal. Pero el término remedios (proveniente del derecho angloamericano y con uso cada vez más extendido en los textos de derecho europeo) tiene la ventaja de su mayor flexibilidad. No está contaminado por la construcción judicialista que históricamente ha acompañado a las medidas de protección del derecho de contratos. Permite incluir tanto las pretensiones como los derechos potestativos. Permite además referirse a las medidas de protección que se desarrollen fuera del proceso (por ejemplo: anulación o resolución extrajudicial, mediante declaración de voluntad)".

7 Carrasco (2010) p. 863. En el mismo sentido, esta vez para el ámbito francés Cornu, en el Vocabulaire juridique de l'Association Henri Capitant (citado en, faure AbBad (2003) p. 135), define el incumplimiento (inexécution) como "non-accomplissement qui peut étre total ou partiel, résulter d'une omission ou d'une initiative, être dû à une faute de la part du debiteur (inexécution fautive) ou à une cause étramgère (inexécution fortuite)".

8 Fueyo (2004) p. 252.

9 Abeliuk (2008) p. 793. En el mismo sentido Gatica (1959) p. 62. “(E)l concepto de incumplimiento comprende, en general, todo caso de inejecución, cualquiera que sea su causa, naturaleza, forma o gravedad”. Por su parte, Vidal (2006), p. 177 señala que "(E)l incumplimiento en su sentido más amplio se confunde con la no realización de la prestación o, en otros términos, con cualquiera desviación del programa o plan ideal de prestación inicialmente acordado por las partes.

10 Ver Vidal (2010) pp. 162-166.
} 
El carácter negativo que puede atribuirse a la noción de incumplimiento en el ámbito nacional permite, a primera vista, estimar que se trata de una noción amplia de incumplimiento, es decir una que cubre cualquier "no realización de la prestación debida o la realización de un modo distinto al debido"11. Sin embargo, esta podría ser una conclusión apresurada.

Luis Díez-Picazo ha señalado, de manera muy correcta en mi opinión, que "En rigor "incumplimiento" no es más que una premisa necesaria para el ejercicio de estas acciones"12. Las acciones a las que se refiere el profesor Díez-Picazo son, fundamentalmente, las de cumplimiento forzado, resolutoria y de indemnización de perjuicios ${ }^{13}$. Podríamos añadir a ellas la disminución del precio.

Si Díez-Picazo lleva razón no cualquier falta de la realización de la prestación debida o la realización de un modo distinto al debido configura, en sentido técnico, incumplimiento contractual, sino, nada más aquellos supuestos de falta de realización o realización defectuosa que constituyen la premisa necesaria para una o más de esas acciones.

Para ilustrar esta idea conviene recordar que en la regulación de la compraventa existen dos supuestos en los que resulta evidente la diferencia entre la omisión de la prestación y el incumplimiento contractual: la venta de cosa que no existe y se supone existente y la denominada teoría de los riesgos.

Tratándose de la cosa que no existe, pero se supone existente, el inciso primero del artículo 1.814 dispone que "La venta de una cosa que al tiempo de perfeccionarse el contrato se supone existente y no existe, no produce efecto alguno". Alessandri Rodríguez ilustra el supuesto de hecho de la norma con una antigua sentencia de la Corte de Apelaciones sobre una compraventa de terrenos de sales potásicas, en la cual se estableció que dichas sales no habían existido nunca ${ }^{14}$.

¿Configura esta situación un incumplimiento de las obligaciones del vendedor? Si se adopta una noción amplia de incumplimiento, la respuesta es desde luego que sí, el vendedor ha dejado de realizar la prestación debida. Así, por ejemplo, se considera en la Convención de Viena sobre Compraventa Internacional de Mercaderías (CV) ${ }^{15}$, los Principios Europeos de Derecho de los Contratos (PECL) ${ }^{16}$ o en los Principios UNIDROIT sobre Contratos Comerciales Internacionales (PCCI $)^{17}$.

Sin embargo, esta no es la opción que asume el Código Civil chileno. Si la cosa no existe $^{18}$, el contrato es totalmente ineficaz por carecer de objeto ${ }^{19}$. Se trata, según advierte

11 Respecto de la noción amplia de incumplimiento puede consultarse Morales (2010), pp. 29-30; Fenoy (2010), pp. 74-75 y Vidal (2011).

12 Dítz-Picazo (2008) p. 654.

13 Esta idea se encuentra bien plasmada en la CISG, sus artículos 45 y 61 articulan los remedios de que dispone el acreedor a partir del hecho del incumplimiento de cualquiera de las obligaciones del deudor.

14 Alessandri (2003 a) p. 194.

15 Ver artículo 79-5. Sobre el precepto puede consultarse SALVAdor (1997) p. 653.

16 Art. 4:102, ver comentario al respecto en Díez-Picazo, Roca y Morales (2002) pp. 219-223.

17 Art. 3.3.

$18 \mathrm{Y}$ esto ha de entenderse como que carezca de realidad, no que no exista en manos del deudor. Al respecto puede consultarse Mario Enrique Villagrán Medina con Guillermo Hernán Godoy Fernández; Sergio Villagrán Medinala (2006).

19 Ver Alessandri (2003 a) p. 193. 
Díez-Picazo, de una antigua regla, cuyos antecedentes pueden rastrearse en el Digesto (18, $1,15)^{20}$, más tarde en las Partidas $(5,5,14)$ y en el artículo 1601 del $\operatorname{Code}^{21}$. Una regla que, además, resulta frecuente en los ordenamientos europeos ${ }^{22}$.

Pues bien, como puede verse, únicamente en un sentido no técnico puede hablarse en este caso de incumplimiento, pues se trataría de uno que no constituye la premisa de ninguno de los remedios propios del incumplimiento contractual, sino más bien de la acción de nulidad absoluta ${ }^{23}$.

El segundo supuesto en el cual no coinciden la ausencia de la prestación con el incumplimiento corresponde a la denominada teoría de los riesgos. En el Código Civil, probablemente existan pocas normas que sean tan tristemente célebres como los artículos 1.550 y $1.820^{24}$. El problema con estas normas no se encuentra en su falta de claridad, sino en que son claramente defectuosas. El defecto consiste, precisamente, en que tratan un caso que debería ser de incumplimiento contractual como si fuera uno de extinción de la obligación por pérdida de la cosa debida.

Como resulta bien sabido, si el vendedor que no entrega la cosa porque esta se destruyó por caso fortuito pendiente su entrega, no incumple -para utilizar el lenguaje del artículo 1.793- con su obligación de dar en la medida en que acredite el caso fortuito y se trate de una obligación de especie o cuerpo cierto. La razón es que su obligación se ha extinguido por caso fortuito ${ }^{25}$.

Pues bien, lo que muestran los dos supuestos de los que me he servido es que no toda omisión de la prestación configura, en un sentido técnico, incumplimiento. Por lo mismo, por amplias que sean las definiciones de incumplimiento que prodiga la doctrina nacional no resulta correcto afirmar, sin más, la amplitud de la noción implícita en la regulación de la compraventa.

\subsection{ManifestaCiOnes DEL InCUMPlimiento}

El incumplimiento contractual puede manifestarse de formas muy diversas. Así, por ejemplo, en su comprensivo estudio comparativo de los tipos de incumplimiento contractual en el civil law y en el common law, Jones y Schlechtriem, identifican, tratándose del civil law, tres grupos de supuestos, el primero de ellos queda configurado por aquellos su-

20 Aunque, según señalan Díez-Picazo, Roca y Morales (2002), pp. 221-222, un romanista de la talla de Betti consideraba que en el derecho romano la regla carecía de la amplitud con que pasó a los códigos civiles decimonónicos.

21 Díez-Picazo (2010) p. 73

22 Sobre el tema puede consultarse Morales (2006 b) p. 118.

23 Situación que según relata Zimmmermann (2008) p. 42, había sido considerada como "perturbadora, tanto desde el punto de vista conceptual como desde el punto de vista práctico" por la doctrina alemana antes de la modificación del régimen del derecho de las obligaciones de 2001.

24 Como señala, con tanta elocuencia, Elorriaga (2002) pp. 33-34: “... debe ser difícil encontrar alguna otra norma dentro del Código Civil que goce del triste privilegio de contar con el más unánime rechazo de la doctrina. Prácticamente no existe autor entre nosotros que habiéndose referido a la problemática de los riesgos no haya dejado de descargar una profunda crítica al criterio de solución de los artículos 1550 y 1820 ".

25 Ver, por ejemplo, Abeliuk (2008) p. 118; López (2005) pp. 576-578 y Vidal (2009) p. 365. Esto, como es evidente, sin perjuicios del Commodum Repraesentationis. Al respecto puede consultarse AlCALde (2008). 
puestos en los que el cumplimiento resulta imposible; el segundo grupo reúne aquellos casos de retardo en el cumplimento; finalmente, el tercer grupo contiene un amplio y disímil conjunto de supuestos cuyo común denominador es que no caben dentro de los otros dos y que incluyen hipótesis de cumplimientos imperfectos, incumplimiento de obligaciones secundarias e incumplimiento anticipado (anticipatory breach) ${ }^{26}$.

Por su parte, en un buen esfuerzo de síntesis, Luis Díez-Picazo ha señalado que es posible detectar dos situaciones de lesión del derecho de crédito, aquella en que el deudor no ha realizado acto alguno dirigido a poner en práctica la prestación comprometida y aquella en que no obstante haber llevado a cabo ciertos actos estos no llegan a concretar el programa de prestación según lo exigía el contrato ${ }^{27}$. A partir de estas situaciones, indica el autor, pueden presentarse combinaciones diversas ${ }^{28}$.

En el ámbito nacional, Abeliuk Manasevich señala que: “...hay incumplimiento cuando la obligación no se cumple, se cumple imperfectamente o se retarda su cumplimiento" 29 . Inmediatamente después, clasifica el incumplimiento, distinguiendo entre aquellos que son voluntarios e involuntarios; los totales y los parciales; definitivos y temporales $y$, en fin, aquellos que generan responsabilidad y aquellos que no ${ }^{30}$. Por su parte, Gatica Pacheco, distingue, en primer lugar, según las causas del incumplimiento, identificando aquellos provocados por hechos imputables a la voluntad del deudor y por hechos ajenos a ella; en segundo lugar, utiliza como criterio la naturaleza del incumplimiento y distingue, la falta total de incumplimiento, su cumplimiento imperfecto y el retado en el incumplimiento ${ }^{31}$. Finalmente, Fueyo Laneri identifica el incumplimiento propio o absoluto, el incumplimiento imperfecto o impropio y el cumplimiento atrasado ${ }^{32}$.

Por su parte, el Código Civil, como se sabe, carece de un tratamiento sistemático de la lesión del crédito, por lo tanto, no ha de extrañar que así como no existe una noción de incumplimiento, sus principales manifestaciones se traten de manera algo oblicua a propó-

\footnotetext{
26 Jones y SChlechtriem (1977) p. 91.

27 Díez-Picazo (2008) p. 654.

28 Díez-Picazo (2008) p. 655. Las situaciones son las siguientes:

La primera situación corresponde a aquella en que "(E)l deudor no ha realizado ninguna prestación en el momento en que estaba obligado a ejecutarla, pero la prestación objetivamente considerada es todavía posible y realizada tardíamente es idónea para satisfacer el interés del acreedor"(Loc. cit.). En la segunda situación tampoco se realizado ninguna prestación en el momento debido y, objetivamente, aún es posible realizarla, pero ya no resulta idónea para satisfacer el interés del acreedor. En la tercera situación el deudor no ha realizado ninguna prestación y la posibilidad de realizarla se ha tornado definitivamente imposible. En la cuarta situación se ha realizado una prestación defectuosa, dentro del tiempo establecido, sin embargo esta es defectuosa, pero, en términos tales, que podría corregirse de manera de lograr la satisfacción del interés del acreedor. Finalmente, la última situación, es idéntica a la cuarta, salvo en el hecho de que los defectos no admiten corrección. Las combinaciones identificadas por Díez-Picazo capturan, según me parece, más adecuadamente la facticidad del incumplimiento. Los criterios aquí resultan ser, de una parte, el hecho de que al tiempo en que era exigible la prestación no se haya ejecutado o se haya efectuado defectuosamente. De otra parte, si no se ha ejecutado, habrá que distinguir si todavía es posible o no y, de serlo, si resulta idónea o no para satisfacer el interés del acreedor. En tercer lugar, si se ha ejecutado defectuosamente, habrá que distinguir si se puede o no corregir.

29 Abeliuk (2008) p. 793. En el mismo sentido Fueyo (2004) p. 252.

30 Abeliuk (2008) p. 793.

31 Gatica (1959) pp. 77-78.

32 Fueyo (2004) pp. 253-254.
} 
sito de la indemnización de perjuicios en el artículo 1.556, distinguiendo la falta de cumplimiento, su cumplimiento imperfecto y el retardo en el cumplimiento.

De las diversas manifestaciones del incumplimiento interesa aquí lo que suele denominarse cumplimiento defectuoso. Tres son las razones que justifican este interés respecto de la compraventa. La primera de ellas es que se trata de un tema al cual la doctrina más tradicional en Chile no ha prestado mayor atención ${ }^{33}$. La segunda razón es que, probablemente, es este el tipo de incumplimiento que tiene lugar con mayor frecuencia tratándose de las obligaciones del vendedor y la tercera razón, como espero mostrar más adelante, consiste en los desafíos dogmáticos de encuadre que presenta este tipo de incumplimiento. Para adelantar el punto, dos preguntas. La primera de ellas es ¿qué es lo que se incumple cuando se cumple defectuosamente, la obligación de entrega o la obligación de saneamiento? La segunda interrogante se refiere a los remedios ¿con qué protección cuenta el comprador frente a un cumplimiento defectuoso? La respuesta a estas dos preguntas debe permitir avanzar a paso firme en la determinación del régimen de los cumplimientos defectuosos en la regulación de la compraventa.

El examen de los cumplimientos defectuosos aconseja comenzar por algún breve esfuerzo analítico que contribuya a esclarecer el uso que damos a la expresión. En este sentido resultará útil determinar cuándo nos encontramos frente a este tipo de incumplimiento. Sobre el particular Díez-Picazo indica que:

"En términos generales, existe cumplimiento inexacto o defectuoso de la obligación siempre que el comportamiento solutorio llevado a cabo por el deudor no se ajuste a los presupuestos que aquel pago reclama para producir plenos efectos liberatorios y satisfactivos" 34 .

De manera que, continúa este autor, los tipos de inexactitud pueden ser los siguientes: "1. ${ }^{\circ}$ La inexactitud relativa a los sujetos del acto de cumplimiento (...)

2..$^{\circ}$ La inexactitud que se refiere al objeto de la prestación, cuando se produce una contravención de los requisitos de identidad e integridad del pago.

3. ${ }^{\circ}$ La inexactitud relativa al lugar de la prestación, que se produce cuando el deudor cumple o pretende cumplir en un lugar diferente del señalado en la obligación.

4. ${ }^{\circ} \mathrm{La}$ inexactitud relativa al tiempo de la prestación, que se reconduce a los supuestos de cumplimiento anticipado y de cumplimiento retrasado" 35 .

Y concluye señalando:

"De todos los casos antes enumerados que se pueden englobar bajo la amplia rúbrica de cumplimiento inexacto de la obligación solo el señalado en segundo lugar requiere un tratamiento especial, pues todos los demás casos encuentran su solución, entre nosotros, dentro de la normativa del pago.

\footnotetext{
33 Basta considerar la alarmante escasez de trabajos sobre vicios redhibitorios, evicción, aliud pro alio, venta de cosa ajena, etc. La situación no es del todo curiosa si se considera, como sugiere VIDAL (2010) pp. 146-147 que en el Código Civil el cumplimiento defectuoso "pasa prácticamente desapercibido".

34 Díez-Picazo (2008) p. 699.

35 Díez-Picazo (2008) pp. 699-700.
} 
Por eso, el cumplimiento inexacto se puede calificar como «ejecución de una prestación defectuosa». La diferencia más importante que esta figura ofrece, frente al incumplimiento definitivo y a la mora es que, así como en estos últimos casos se ha producido una omisión total de prestación, en el nuestro existe un comportamiento positivo del deudor dirigido a cumplir, que, sin embargo, no se ajusta a los términos del programa establecido en el acto de constitución de la relación obligatoria. Dicho más claramente, no es que el deudor no haya hecho nada, sino que lo que ha hecho está mal hecho ${ }^{36}$.

Se trata de una larga cita, pero ampliamente justificada. En primer lugar, la noción de cumplimiento defectuoso agrupa diversos supuestos, sin embargo, como sucede en el ámbito español, tratándose del ordenamiento jurídico chileno, los que realmente presentan problemas y que no pueden solucionarse sin más acudiendo a reglas del pago -generales o específicas de la compraventa- son las relativas al objeto de la prestación; tratándose de la compraventa, a la cosa.

Por lo tanto, un examen del régimen de los cumplimientos defectuosos debe prestar especial atención a aquellos supuestos en los cuales la deficiencia se predica de la cosa, ya sea porque, como se verá, esta no resulta conforme a las especificaciones del contrato o bien porque existen derechos de terceros ${ }^{37}$.

36 Díez-Picazo (2008) p. 700.

37 Al formular la distinción entre falta de conformidad y derechos de terceros sigo la CV, Las normas son las siguientes. El artículo 35, respecto de la falta de conformidad, dispone que: 1) El vendedor deberá entregar mercaderías cuya cantidad, calidad y tipo correspondan a los estipulados en el contrato y que estén envasadas o embaladas en la forma fijada por el contrato. 2) Salvo que las partes hayan pactado otra cosa, las mercaderías no serán conformes al contrato a menos: a) que sean aptas para los usos a que ordinariamente se destinen mercaderías del mismo tipo; b) que sean aptas para cualquier uso especial que expresa o tácitamente se haya hecho saber al vendedor en el momento de la celebración del contrato, salvo que de las circunstancias resulte que el comprador no confió, o no era razonable que confiara, en la competencia y el juicio del vendedor; c) que posean las cualidades de la muestra o modelo que el vendedor haya presentado al comprador; d) que estén envasadas o embaladas en la forma habitual para tales mercaderías o, si no existe tal forma, de una forma adecuada para conservarlas y protegerlas. 3) El vendedor no será responsable, en virtud de los apartados a) a d) del párrafo precedente, de ninguna falta de conformidad de las mercaderías que el comprador conociera o no hubiera podido ignorar en el momento de la celebración del contrato.

Por lo que toca a las pretensiones de terceros, interesan los artículos 41 y 42. Según el primero: El vendedor deberá entregar las mercaderías libres de cualesquiera derechos o pretensiones de un tercero, a menos que el comprador convenga en aceptarlas sujetas a tales derechos o pretensiones. No obstante, si tales derechos o pretensiones se basan en la propiedad industrial u otros tipos de propiedad intelectual, la obligación del vendedor se regirá por el artículo 42. Por su parte, el artículo 42 dispone que: 1) El vendedor deberá entregar las mercaderías libres de cualesquiera derechos o pretensiones de un tercero basados en la propiedad industrial u otros tipos de propiedad intelectual que conociera o no hubiera podido ignorar en el momento de la celebración del contrato, siempre que los derechos o pretensiones se basen en la propiedad industrial u otros tipos de propiedad intelectual: a) en virtud de la ley del Estado en que hayan de revenderse o utilizarse las mercaderías, si las partes hubieren previsto en el momento de la celebración del contrato que las mercaderías se revenderían o utilizarían en ese Estado; o b) en cualquier otro caso, en virtud de la ley del Estado en que el comprador tenga su establecimiento. 2) La obligación del vendedor conforme al párrafo precedente no se extenderá a los casos en que: a) en el momento de la celebración del contrato, el comprador conociera o no hubiera podido ignorar la existencia del derecho o de la pretensión; o b) el derecho o la pretensión resulten de haberse ajustado el vendedor a fórmulas, diseños y dibujos técnicos o a otras especificaciones análogas proporcionados por el comprador. 


\subsection{LAS OBLIGACIONES DEL VENDEDOR Y LOS REMEDIOS FRENTE AL INCUMPLIMIENTO}

Ante todo, al definir la compraventa, el artículo 1.793 dispone que una parte, el vendedor, "se obliga a dar una cosa". Por lo tanto, en su formulación más sintética, la obligación del vendedor consiste en un dar.

Por su parte, el artículo 1.824 modula esta obligación, distinguiendo la obligación de entrega de la obligación de saneamiento.

En tercer lugar, el artículo 1.837 dispone que:

La obligación de saneamiento comprende dos objetos: amparar al comprador en el dominio y posesión pacífica de la cosa vendida, y responder de los defectos ocultos de esta, llamados vicios redhibitorios.

Considerando en conjunto estos preceptos, la obligación del vendedor suele, siguiendo a Alessandri Rodríguez, formularse de la siguiente manera: “...el vendedor se obliga a poner al comprador en posesión tranquila y pacífica de la cosa vendida" 38 .

En lo que respecta a los remedios frente al incumplimiento de las obligaciones del vendedor convendrá comenzar por el artículo 1.826 según el cual:

"Si el vendedor por hecho o culpa suya ha retardado la entrega, podrá el comprador

a su arbitrio perseverar en el contrato o desistir de él, y en ambos casos con derecho para ser indemnizado de los perjuicios según las reglas generales”.

Según ha señalado Alessandri Rodríguez: "Este artículo no es sino la reproducción de la regla general que para todo contrato sinalagmático consigna el artículo 1.489 del Código Civil"39. Si esto es correcto, entonces puede afirmarse que, tratándose de un incumplimiento consistente en la omisión de la prestación -es decir, consistente en no entregar-, la protección del comprador queda configurada por el régimen general de remedios frente al incumplimiento contractual del Código Civil. Es decir, frente a la omisión de la prestación, el comprador puede recurrir al cumplimiento forzado o a la resolución del contrato y, en ambos casos, con indemnización de perjuicios si correspondiese ${ }^{40}$.

Junto a este régimen general de remedios, el Título XXIII del Libro IV del Código Civil dispone de otros regímenes de remedios que voy a denominar "especiales" a propósito de los defectos de cabida (arts. 1.831-1835), de la evicción (arts. 1.838-1.856) y de los vicios redhibitorios (arts. 1.857-1.870).

Denomino especiales a estos regímenes de remedios porque cada uno de ellos configura un sistema de acciones de tutela del comprador que, con mayor o menor intensidad, se diferencia del régimen general ${ }^{41}$. Así, por ejemplo, tratándose de la cabida, el artículo 1.832 establece que si la cabida real es menor que la declarada el vendedor deberá dismi-

\footnotetext{
38 AlEssandri (2003 b) p. 659. Sin embargo, existen opiniones en contrario, ver especialmente, UGARTE (1970).

39 Alessandri (2003 b) p. 779.

40 Ver, por ejemplo, Nieves Rodríguez Cañas; con Juan Espinola Prieto (1990).

41 Ver Morales (2006 a) p. 25.
} 
nuir el precio (remedio que no se encuentra considerado en el régimen general). Algo similar sucede respecto de la disminución del precio frente a la presencia de vicios redhibitorios en el artículo 1.860. Por otra parte, a propósito del régimen de la evicción, los artículos 1.847 a 1.850 contienen disposiciones sobre restituciones e indemnizaciones que se alejan de las propias del régimen general ${ }^{42}$. En tercer lugar, y como resulta bien sabido, tanto las acciones de cabida como las propias de la evicción y aquellas derivadas de la presencia de vicios redhibitorios poseen reglas de prescripción especiales ${ }^{43}$.

Tiempo de una breve recapitulación. La obligación del vendedor consiste en un dar que se modula en una obligación de entrega y una de saneamiento; por otra parte, frente al incumplimiento de las obligaciones de vendedor conviven un régimen general de remedios y otros especiales. Como adelanté ya y espero desarrollar en la segunda parte de este trabajo, una situación como esta presenta, al menos, dos severas interrogantes sobre el régimen de las entregas defectuosas: ¿a qué obligación corresponden? Y ¿qué remedios confieren al comprador?

3.

Los materiales suministrados en la primera parte de este trabajo -aunque presentados tan resumidamente- deberían ser suficientes para aproximarse al régimen de los cumplimientos defectuosos en la compraventa regulada por el Código Civil.

Intento esta aproximación considerando las dos cuestiones ya anunciadas. La primera de ellas es cómo se incardina el cumplimiento defectuoso en la modulación del artículo 1.824. La segunda, consiste en determinar si la protección del comprador se articula a través del régimen general de remedios o bien a través de los regímenes especiales.

No pretendo agotar aquí los supuestos de cumplimientos defectuosos, no resulta posible en un trabajo de estas características ni -me parece- necesario, para las pretensiones más bien preliminares de este artículo. Con todo, estoy bastante seguro de que los supuestos que considero constituyen una muestra suficientemente representativa y dogmáticamente desafiante de los cumplimientos defectuosos. A continuación -y en este orden- me ocupo del aliud pro alio, los defectos de cabida, los vicios redhibitorios, la venta de cosa ajena y la evicción.

\subsection{ALIUD PRO ALIO}

Como nos recuerda Nieves Fenoy la doctrina del aliud pro alio (una cosa por otra) tiene sus orígenes en el derecho romano a propósito de la determinación de la relevancia

\footnotetext{
42 En opinión de Alessandri Rodríguez (ID., t. II-1, 117) el artículo 1.847 sería una disposición especial que derogaría las reglas generales del Título XII del Libro IV del Código Civil.

43 Respecto de la cabida puede consultarse el artículo 1.834; respecto de la evicción existe regla especial a propósito de la acción de saneamiento (art. 1.856); finalmente, por lo que toca a las acciones edilicias, existen reglas especiales tanto respecto de la redhibitoria (art. 1.866) como de la quanti minoris (art. 1.869) y se discute la regla de prescripción de la acción de perjuicios del artículo 1.861. Al respecto puede consultarse GuZMÁN (2007).
} 
del error en la substancia, específicamente en D. 18.1.9.2 $2^{44}$. Sin embargo, sigue esta autora, el Tribunal Supremo Español la ha utilizado más bien en relación con el incumplimiento de las obligaciones del vendedor ${ }^{45}$.

Por su parte, José Ramón de Verda y Beamonte, revisando las decisiones de los tribunales superiores españoles al respecto, ha concluido que la doctrina puede asumir dos versiones ${ }^{46}$. Según la primera de ella, existe aliud pro alio en aquellos supuestos en los cuales se entrega una cosa diversa en su identidad física a la prevista en el contrato. A esta primera versión Verda y BeAmonte la denomina "material" 47 . Junto a ella, el autor identifica una segunda versión, a la cual denomina "funcional". En esta segunda versión, el aliud pro alio comprendería supuestos en que existe identidad física entre lo debido y lo entregado, sin embargo la cosa resulta

"funcionalmente incapaz de desempeñar el destino económico-social a que se destina $y$, por ende, de satisfacer aquellas concretas necesidades que indujeron al comprador a efectuar su adquisición" 48 .

El mismo autor suministra un abultado elenco de casos en los que el Tribunal Supremo español ha aplicado la doctrina en cuestión ${ }^{49}$. Entre ellos los siguientes: el motor cuya entrega se debía tiene una potencia de $75 \mathrm{HP}$, el entregado únicamente de $27 \mathrm{HP}$; el departamento entregado tiene una grieta irreparable; unas máquinas vibrotamices para tratamiento de carbón no corresponden a la marca pactada; un molino de piensos tiene una capacidad de moliendas sensiblemente inferior a la convenida; las máquinas de juegos recreativas vendidas como nuevas son, en realidad, usadas; el parquet entregado está afectado por carcoma en estado larvario; los equipos informáticos entregados son obsoletos e ineficaces para desempeñar la función para la cual se adquirieron; los relojes vendidos, supuestamente de una prestigioso marca resultan, en definitiva falsificaciones.

En el ámbito nacional existen dos importantes sentencias que se han servido de la doctrina del aliud pro alio frente a incumplimientos del vendedor.

La primera de ellas es la conocida sentencia de la Corte Suprema de fecha 27 de julio de $2005^{50}$. Se trata de un contrato de compraventa de sal nitrificada en una concentración del $0,8 \%$, sin embargo, la vendedora entregó la cantidad acordada, pero nitrificada al $8,0 \%$. Por su parte, la compradora demandó la resolución del contrato por incumplimiento de la obligación de entrega y, en subsidio, solicitó la rescisión por la presencia de vicios redhibitorios. Convendrá reproducir extensamente los razonamientos de la Corte Suprema

\footnotetext{
44 Fenoy (1996) p. 196.

45 Fenoy (1996) pp. 196-197.

46 Verda y Beamonte (2009) pp. 312-317.

47 Verda y Beamonte (2009) p. 314.

48 Verda y Beamonte (2009) p. 314.

49 Verda y Beamonte (2009) pp. 314-316.

50 Cecinas La Preferida S.A. con sociedad Comercial Salinak Limitada (2006). Con comentario en Revista Chilena de Derecho Privado, No 6, 2006, pp. 155-162.
} 
contenidos en la sentencia que rechaza el recurso de casación en el fondo intentado por la vendedora.

10) Que el conflicto de autos se resuelve analizando el cumplimiento de las obligaciones por parte del vendedor, de las cuales la primera es entregar la cosa vendida al comprador, lo que en este caso se hizo, pero en términos objetados por este y la segunda, es la obligación de garantía, que a su turno comprende los vicios redhibitorios y el saneamiento de la evicción.

$2^{\circ}$ ) Que, el artículo 1.828 del Código Civil expresa que "el vendedor es obligado a entregar lo que reza el contrato", de lo que se sigue que, aunque en el caso de autos el vendedor cumplió con su obligación de entregar la cosa la sal lo hizo en forma imperfecta al entregar sal en una concentración distinta a la requerida por el comprador. Esta materia se encuentra tratada en el artículo 1.454 del Código Civil, referida al error de hecho que se produce cuando "la sustancia o calidad esencial del objeto sobre el que versa el acto o contrato, es diversa de lo que se cree".

$3^{\circ}$ ) Que, en el caso de autos, no se ha demandado la nulidad del contrato por la existencia de este error sustancial, sino que la resolución del mismo, conforme lo faculta el artículo 1.489 del Código Civil, esto es, que el contrato se deje sin efecto por el incumplimiento del vendedor, con indemnización de perjuicios y, en subsidio "la rescisión", como dice la ley, por vicios redhibitorios, debiendo la sentencia que se dicte limitarse al análisis de estas pretensiones y fundamentos.

De esta manera, el conflicto jurídico a que debe abocarse el sentenciador, es determinar cuál es la sanción por el hecho de haber entregado el vendedor una cosa distinta a la comprada y que, no solo no servía para el objeto que buscaba el comprador, sino que, además, le habría producido graves perjuicios.

40) Que, habiendo sido recibida la cosa comprada, se ha producido lo que la doctrina llama el cumplimiento imperfecto, porque el vendedor cumplió su obligación de entregar sin reclamo de parte del comprador, pero en definitiva, como se ha señalado, el producto resultó ser otro diferente al comprado.

$\left.5^{\circ}\right)$ Que corresponde, entonces, determinar cuál es la sanción para este caso por haberse entregado una cosa diferente a la comprada.

A primera vista, pareciera que se trataría de un caso de vicio redhibitorio, definido en el artículo 1.857 del Código Civil, como la acción que tiene el comprador para pedir que se "rescinda" la venta o se rebaje proporcionalmente el precio, por los vicios ocultos de la cosa vendida.

Sin embargo, ha de destacarse que la acción antedicha, cuyos requisitos de procedencia se encuentran en el artículo 1.858 del Código Civil, constituye una excepción a la regla general de que el incumplimiento de las obligaciones de un contrato bilateral da origen a la acción resolutoria, debiendo entenderse que aun cuando el legislador califica constantemente la acción por vicios redhibitorios como una acción rescisoria, lo cierto es que, en verdad, es una acción resolutoria especial y con reglamentación diferente a la regla general del artículo 1.489 del texto legal señalado. 
60) Que, en consecuencia, la situación se traduce en que, ante el cumplimiento imperfecto de la obligación de entregar, puede suceder que se reúnan los requisitos de los vicios ocultos, en cuyo caso se aplican las normas del párrafo $8^{\circ}$ del Título XXIII del Libro Cuarto del Código Civil, pero si no se dan dichas exigencias puede reclamarse el cumplimiento de la obligación de entregar por parte del vendedor, a través del artículo 1.489 del Código Civil, si concurren los presupuestos que exige la norma, dando lugar así a la aplicación de la condición resolutoria tácita de este precepto de aplicación general.

70) Que, de acuerdo a las disposiciones que reglamentan la institución de los vicios ocultos, ellas se aplican cuando entregada la cosa realmente vendida, esta resulta tener un vicio existente al tiempo de la venta, pero que no puede ser advertido por el comprador, lo que en este caso se cumple, como se encuentra establecido en autos. Pero ello solo puede tener lugar cuando la cosa entregada es realmente la vendida, lo que no acontece en autos, donde la cosa entregada es otra, como ha quedado establecido en la sentencia de primer grado.

Por ende, no cumpliéndose esta exigencia fundamental para aplicar la acción redhibitoria, debemos volver a la regla general del artículo 1.489 del Código Civil, ya que el incumplimiento del vendedor reúne todos los requisitos para que proceda la resolución del contrato.

(...)

9०) Que, conforme lo razonado precedentemente, corresponde acoger la acción principal de resolución de contrato deducida por el actor.

Pues bien, se trata de una extensa cita y, por lo mismo, para su análisis, resultará útil desmontarla en piezas más pequeñas.

En primer lugar, resulta interesante constatar que el Tribunal considera que un caso como este configura el supuesto de hecho de la nulidad por error ${ }^{51}$. Sin embargo, advierte, esta no es la forma a través de la cual la demandante ha canalizado su pretensión de desvincularse del contrato. La ha canalizado a través de una acción resolutoria que, como se advierte de la lectura del considerando noveno es acogida.

Al considerar las cosas de esta manera la Corte Suprema implica dos puntos muy importantes a los cuales convendrá prestarles atención.

El primero de ellos es que, en ciertos casos, las mismas circunstancias configuran a la vez el supuesto de hecho de la acción de nulidad por error y la acción resolutoria por

\footnotetext{
51 Alessandri (2003c) pp. 186-187 consideraba -equivocadamente en mi opinión- que no se presentaba concurso entre las figuras del error substancial y la de los vicios redhibitorios. En su opinión, la diferencia podía expresarse del siguiente modo (Alessandri (2003c) p. 188): El error en la sustancia o calidad de la cosa importa la entrega de una cosa diferente de la que se creyó comprar o a la cual falta una cualidad esencial que se tuvo en vista al adquirirla: pero que no adolece de ningún vicio. La cosa sirve para el uso a que se le destina. Los vicios redhibitorios, en cambio, suponen que la cosa se la misma, que su sustancia no ha variado; pero que adolece de algún defecto que disminuye su importancia o que la hace inadecuada para su uso.
} 
incumplimiento contractual. En otras palabras, existen ciertas situaciones en las que se presenta concurso de normas entre la acción de nulidad por error y la resolutoria ${ }^{52}$.

El segundo punto se refiere a la forma en que se resuelve ese concurso de normas. Según señala LARENZ, constatada la existencia de un concurso pueden tener lugar las siguientes consecuencias ${ }^{53}$ : (i) que se apliquen las consecuencias de dos o más proposiciones jurídicas copulativamente, un cuyo caso se habla de una aplicación acumulada ${ }^{54}$; (ii) que se apliquen las consecuencias de dos o más proposiciones jurídicas, pero únicamente en el sentido que el titular de las acciones pueda elegir la proposición según la cual canalizará su pretensión, en cuyo caso puede hablarse de acumulación alternativa ${ }^{55}$; (iii) que reciba aplicación únicamente una de las proposiciones jurídicas, excluyendo a la otra ${ }^{56}$. En este caso, tratándose del concurso entre la nulidad por error y la resolución, la Corte Suprema parece considerar que se resuelve aplicando la acumulación alternativa.

En segundo lugar, la Corte Suprema estima que no existe concurso entre vicios redhibitorios y resolución toda vez que no se satisface el supuesto de hecho de la aplicación de estos últimos -diré inmediatamente por qué-. Añade que si existiera dicho concurso "se aplican las normas del párrafo $8^{\circ}$ del Título XXIII del Libro Cuarto del Código Civil”. A partir de esa afirmación puede concluirse que el Tribunal -aunque obiter dicta- estima que si existiera concurso las disposiciones de los vicios redhibitorios excluirían la posibilidad del acreedor de dirigirse al régimen general de remedios.

En tercer lugar, la razón de que no exista concurso entre el régimen de los vicios redhibitorios y el régimen general de remedios -aunque el Tribunal no utilice la expresión- es la doctrina del aliud pro alio en su versión material. Así se desprende de la lectura del considerando séptimo:

Que, de acuerdo a las disposiciones que reglamentan la institución de los vicios ocultos, ellas se aplican cuando entregada la cosa realmente vendida, esta resulta tener un vicio existente al tiempo de la venta, pero que no puede ser advertido por el comprador, lo que en este caso se cumple, como se encuentra establecido en autos. Pero ello

\footnotetext{
52 Me he detenido sobre este tema en De la Maza (2011). Para otras posibles situaciones de este concurso pueden consultarse Consorcio de Trasportes Trancura Limtada contra Tocale Tuna, Romilio Perfecto (2010) en la cual se resuelve aplicando la disciplina del error un caso que corresponde perfectamente a la resolución del contrato, Por otra parte, puede consultarse también Casa do Brasil Sociedad Limitada con Mall Puente S.A.(2008) en la cual el Tribunal parece considerar que se puede producir un concurso entre las acciones de nulidad derivada de un error substancial y la de terminación de arrendamiento.

53 Larenz (1966) p. 188.

54 Así, por ejemplo, sucede con el incumplimiento del deber de fidelidad en el matrimonio que puede determinar la separación judicial (artículo 26 Ley de matrimonio civil), la revocación de ciertas donaciones (artículo 172 CC), la disminución de los alimentos (artículo 175 CC), y la pérdida de la calidad de legitimario (artículo 1182 CC).

55 Es el caso, por ejemplo, de los accidentes del trabajo respecto de los cuales nuestros tribunales han aceptado que el trabajador canalice su pretensión reparatoria a través de las reglas de la responsabilidad contractual o extracontractual. Ver Corral (2010) p. 7.

56 Esta es la posición que, en general, asumen los tribunales chilenos en el caso de concurso entre el régimen de la responsabilidad contractual y extracontractual. Para una muestra de sentencias en este sentido puede consultarse BARros (2006) p. 1062, nota 200.
} 
solo puede tener lugar cuando la cosa entregada es realmente la vendida, lo que no acontece en autos, donde la cosa entregada es otra ${ }^{57}$.

En cuarto lugar, la Corte Suprema considera que se trata de cumplimiento imperfecto en el cual se ha incumplido con la obligación de entrega y dicho incumplimiento autoriza el recurso al régimen general de remedios. Esto es lo que explica que el contrato se declare resuelto con cargo al artículo 1.489 .

La segunda sentencia es de la Corte de Apelaciones de Concepción de 1 de diciembre de $1993^{58}$. Se trata de la compraventa de un departamento respecto del cual se hizo la entrega material, sin embargo, la compradora alega que dicha entrega no fue exacta pues dicho inmueble se encontraba gravado por una hipoteca y una prohibición de gravar, enajenar y arrendar. En razón de la existencia de dichos gravámenes la compradora considera incumplida la obligación del vendedor y, por lo tanto, solicita que se le ordene alzar la hipoteca y la prohibición y no haciéndolo se le embarguen bienes suficientes para lograr ese alzamiento.

En lo que interesa respecto del aliud pro alio ${ }^{59}$, la Corte Consideró que: ...el vendedor está obligado a entregar lo que reza el contrato, regla dispuesta a propósito de la obligación de entregar (Tít. XXIII, Lib. IV) y que hace de la obligación de entregar no solamente un paso material y jurídico de la cosa, sino también comprender en ella, una identidad entre aquello que forma el objeto de la obligación y lo efectivamente entregado, puesto que, en definitiva, no se trata sino de la particularización de la regla general del artículo 1569 que impone como requisito objetivo del cumplimiento la exactitud, identidad e integridad de la prestación, pues guarda aún vigencia la fórmula del Derecho Romano aliud pro alio, invito creditori solvi non potest (I.2, 1, D.1, así, José Beltrán Heredia y Castaño, El Cumplimiento de las Obligaciones, págs. 209 y sgts. Madrid 1956).

En las palabras de eminentes autores: Cuando la compraventa recaiga sobre un cuerpo cierto, el vendedor está obligado igualmente a entregar la cosa tal y como ha sido convenida, querida por las partes; en consecuencia, si la cosa vendida y entregada está afectada por un vicio oculto, ignorado por el comprador, o si lleva consigo una posibilidad de evicción, el vendedor no ha cumplido con su obligación de entrega (H.L.y J. Mazeaud, Lecciones de Derecho Civil, parte 3, vol., n. 937).

Un primer comentario a propósito de este extracto se refiere al artículo 1.828. Entiende la Corte de Apelaciones de Concepción que la obligación de entrega no se agota en el traspaso material y jurídico de la cosa, sino -para utilizar la fórmula que emplea dicho precepto- "en lo que reza el contrato". Y lo que reza el contrato es una particularización de la regla del pago contenida en el artículo 1.569, por lo mismo, entonces, aún si existe en-

57 Subrayado añadido.

58 Silva Escandón María Gabriela contra Dosque Contreras María Luisa (1993).

59 Más adelante volveré sobre esta sentencia a propósito del tratamiento de la evicción, ver pp. 24-26. 
trega material y jurídica, pero la cosa posee un vicio oculto o lleva consigo la posibilidad de evicción existe incumplimiento de la obligación de entrega.

El segundo comentario corresponde a la versión de la doctrina del aliud pro alio de la que se sirve la Corte. A diferencia del caso anterior ya no se trata de un problema de identidad física de la cosa, no hay dudas de que ese era el departamento objeto de la obligación del vendedor. La cuestión es más bien funcional, ese departamento no cumple con la función garantizada por el contrato, en ese único sentido es una cosa por otra. Y aquí resultan especialmente pertinentes las palabras de Nieves Fenoy respecto de esta versión de la doctrina del aliud pro alio:

...lo jurídicamente relevante es el objeto que el contrato diseña, y no, el objeto existente en la realidad. Es decir, sobre el vendedor pesa una obligación de resultado (garantía), consistente en dar una cosa útil al comprador, que, a veces, es expresamente pactada, y otras, que son la mayoría, está implícito en el contrato.

Las sentencias consideradas muestran algunos puntos que conviene subrayar antes de pasar al segundo supuesto de entregas defectuosas.

En primer lugar, resulta posible que el supuesto de hecho de la acción resolutoria coincida con el supuesto de hecho de la acción de nulidad por error. Cuando esto sucede, aparentemente, la solución es la acumulación alternativa, es decir, el comprador elige el régimen a través del cual encauzará su pretensión.

En segundo lugar, también resulta posible que el supuesto de hecho de la acción resolutoria coincida con el de los vicios redhibitorios. En esta situación, todo parece indicarlo, el régimen especial deroga al general.

Finalmente, en tercer lugar, nuestros tribunales, se han servido de la doctrina del aliud pro alio tanto en su versión material como en su versión funcional.

\subsection{LOS DEFECTOS DE SUPERFICIE}

Luis Díez-Picazo nos recuerda los orígenes históricos de la cabida que arrancan del derecho romano (D. $18,1,40 ; 19,1,4$ y $21,2,69)^{60}$. Señala, además, que en supuestos de ventas por medidas la voluntad negocial se forma en consideración a la extensión superficial del predio y que, por lo tanto, el precio depende de ella ${ }^{61}$.

Tratándose del Código Civil, la cuestión de las ventas por cabida posee un tratamiento diferenciado según si se trata de predios rústicos o de predios urbanos. Como resulta bien sabido, el artículo 1.831 únicamente se refiere a los predios rústicos. En consideración a esta norma ALESSANDri RodríGuez ha entendido que:

60 Díez-Picazo (2010) p. 101. Ver también Morales (2006 b) p. 101.

61 Díez-Picazo (2010) p. 101. 
Las reglas que establecen los artículos 1.831 y siguientes del Código Civil, relativas a la forma en que pueden venderse los inmuebles en cuanto a su cabida, se aplican únicamente a los predios rústicos y no a los urbanos ${ }^{62}$.

De esta manera lo han entendido los tribunales. Así lo atestiguan no solo las antiguas sentencias que cita Alessandri Rodríguez, sino que, además, una muy reciente sentencia de la Corte Suprema ${ }^{63}$ sobre la cual convendrá detenerse.

Los hechos del caso quedan configurados por la venta de un predio urbano como especie o cuerpo cierto. Según consta en la escritura de compraventa, la compradora (que en el juicio es la demandante) recibió el inmueble a su entera satisfacción. Sin embargo, con posterioridad demandó indemnización de perjuicios a la inmobiliaria vendedora. Señaló que a ella se le había ofrecido la venta de un departamento de 111,29 metros cuadrados útiles. Una vez celebrado el contrato, se percató de que la superficie real total era inferior a la ofrecida en 9,67 metros cuadrados. Por esta razón solicita al tribunal que se condene a la inmobiliaria al pago de 291 unidades de fomento por indemnización de perjuicios por los metros faltantes y a la suma de $\$ 5.000 .000$ por concepto de daño moral.

En su defensa, uno de los argumentos de la inmobiliaria demandada consistió en señalar que el fallo de la Corte de Apelaciones que acogía la pretensión indemnizatoria infringía los artículos 1.833 y 1.835 en la medida en que el fallo del tribunal de alzada limitaba su aplicación a la venta de predios rústicos, olvidando los sentenciadores que el predio se vendió como especie o cuerpo cierto. La Corte Suprema desechó este argumento pues consideró que los artículos 1.833 y 1.835 no resultaban aplicables a las ventas de predios urbanos, por lo mismo no es correcta la aplicación analógica que realiza de ellos la recurrente.

La sentencia es interesante no solamente porque establece con claridad la aplicación de las reglas de la cabida a los predios rústicos, sino además -y especialmente- porque de ella se sigue que, tratándose de predios urbanos, los defectos de superficie configuran una entrega defectuosa que, en la modulación del artículo 1.824 corresponde a un incumplimiento de la obligación de entrega y que permite al comprador acudir al régimen general de remedios.

Distinta parece ser la cuestión cuando se trata de predios rústicos pues, aparentemente, en ese supuesto las reglas de la cabida desplazan a los remedios generales. Así parece desprenderse de la sentencia fecha 16 de noviembre de 2009 de la Corte de Apelaciones de Valdivia ${ }^{64}$. Me serviré de ella generosamente respecto de la evicción, por lo tanto ahora únicamente me interesa en lo que toca a la cabida.

Los hechos, en la versión más resumida consisten en que un banco comercial vende "ad corpus" un predio rústico adquirido por pública subasta. El predio fue entregado materialmente al comprador a su entera satisfacción y se realizó la inscripción pertinente. Algunos meses después de la tradición el comprador se enteró de que terceros alegaban derechos sobre el predio. El comprador estima que ha existido un incumplimiento contractual y bus-

\footnotetext{
62 Alessandri (2003 b) p. 804.

63 Muñoz Carvajal Carmen c. Inversiones E Inmobiliaria Las Nieves (2011).

64 Toro Mancilla, Rodrigo cl Banco Santander (2009).
} 
ca recurrir al régimen general de remedios, específicamente al indemnizatorio. El tribunal de primera instancia acoge la pretensión. Sin embargo, en alzada, la Corte de Apelaciones la rechaza. En general, los razonamientos de la Corte se refieren a la evicción, no obstante lo anterior, en un considerando, estima que si se acogiera el incumplimiento tal y como lo alega el demandante esto también traería consecuencias para el régimen de la cabida. Esa es la consideración que interesa aquí. En opinión de la Corte considerar el incumplimiento como lo hace el demandante:

Hace inoperante el sistema dicotómico de venta de inmuebles según cabida o como cuerpo cierto, que consagran los artículos 1.831 a 1.834 del Código Civil. Según esas normas, como se sabe, "un predio rústico puede venderse con relación a su cabida o como una especie o cuerpo cierto" y cuando se vende como especie o cuerpo cierto, tal como se pactó expresamente en el contrato de autos, "no habrá derecho por parte del comprador ni del vendedor para pedir rebaja o aumento del precio, sea cual fuere la cabida del predio." A lo más, en estos casos, y cuando se vende "con señalamiento de linderos" y no se entrega todo lo comprendido en ellos, deberá el vendedor sufrir una disminución proporcional del precio; o en casos extremos, optar por desistir del contrato, todo ello conforme lo dispone el artículo 1.833 del Código Civil. En otros términos, la situación de diferencias de cabida respecto de inmuebles, de tanta frecuencia práctica, ha sido prevista por el legislador, y se ha resuelto de modo de garantizar máximamente la conservación del negocio jurídico, según se desprende con claridad de las normas citadas, y antes, de la regulación de los artículos 1.831 y 1.832 del Código Civil.

Lo que la Corte parece, entonces, estimar -aunque implícitamente- es que resulta posible que se configure un concurso entre las normas de la cabida y aquellas propias del régimen general de remedios, sin embargo, ese concurso se resuelve a través del desplazamiento de las reglas generales por las particulares de la cabida. Se trata, sin duda, de un incumplimiento de la obligación de entrega, sin embargo, se trata de un incumplimiento que únicamente autorizaría el recurso a las normas especiales de la cabida.

¿Qué se aprende de estas dos sentencias? En primer lugar, que resulta posible la coincidencia entre el supuesto de hecho de la cabida y el de la acción resolutoria. En segundo lugar, que cuando eso sucede el régimen especial parece desplazar al general. En tercer lugar, comparando ambas sentencias, se advierte que cuando se trata de predios urbanos, los defectos de superficie carecen de un régimen especial, por lo tanto, el comprador podrá recurrir al régimen general de remedios.

\subsection{Vicios REDHIBITORIOS}

El régimen de los vicios redhibitorios que adopta el Código Civil tiene sus orígenes en el derecho romano. Según Jörs y Kunkel, el Edicto curul imponía a los vendedores de animales y esclavos una obligación de hacer públicos algunos de los defectos de sus mer- 
cancías $^{65}$. Frente a cualquiera de estos defectos u otros graves ${ }^{66}$, el comprador disponía de dos acciones: la redhibitoria y la quanti minoris. La primera de ellas le permitía recuperar el precio pagado, restituyendo la cosa comprada. La segunda acción le otorgaba una reducción del precio pagado. Ni el ejercicio de la acción redhibitoria, ni el de la quanti minoris precisaban acreditar ningún grado de culpa del vendedor ${ }^{67}$.

Este funcionamiento objetivo se mantiene en el Código Civil, salvo respecto de la acción indemnizatoria del artículo $1.861^{68}$. Ese es el régimen de acciones propio de los vicios redhibitorios y cuando se acude a él, qué duda cabe, el incumplimiento queda encapsulado dentro de la obligación de saneamiento. Esto debería resultar suficientemente obvio. Lo que no parece tan evidente es si frente al cumplimiento imperfecto que supone entregar una cosa con vicios redhibitorios puede recurrirse, además, al régimen general de remedios.

Para explorar esta cuestión convendrá, preliminarmente, una breve precisión que aligere el riesgo de equívocos.

No cualquier defecto, por grave y oculto que sea constituye en el sentido del Código Civil un vicio redhibitorio. Como lo ha entendido la doctrina, los vicios redhibitorios se refieren a la materialidad de la cosa, por lo tanto no alcanzan a defectos en la situación jurídica de esta ${ }^{69}$. Así lo han aceptado también nuestros tribunales. En este sentido, en una sentencia de 10 de marzo de 1988, la Corte de Apelaciones de Santiago, revocando la sentencia de primera instancia, negó lugar a la acción rescisoria del comprador de un vehículo internado ilegalmente a Chile ${ }^{70}$. Entendió la Corte que, no obstante el vicio fuera oculto, no era físico, por lo tanto no daba lugar a una acción redhibitoria. Sin embargo -aunque no se discutió en el caso- parece bastante probable, atendida la gravedad de la situación, que una acción resolutoria por incumplimiento si hubiera procedido ${ }^{71}$.

65 Jörs y Kunkel (1937) p. 335. Así, por ejemplo, la locura en los esclavos (D. 21,1, 1, 9), los padecimientos del hígado, del pulmón (D. 21, 1, 12, 4) y de la vejiga (D. 21, 1, 14, 4), las paperas (D. 21, 1, 14, 9), o la epilepsia (D. 21, 1, 53).

66 No cualquier defecto justificaba la protección edilicia. Así, por ejemplo, no se consideraba como defecto grave el fanatismo de un esclavo (D. 21, 1, 1, 9), su timidez, carácter codicioso y avaro, iracundo (D. 21, 1, 1, 11), melancólico (D. 21, 1, 2), soberbio, giboso o encorvado, que padeciera comezón o sarna (D. 21, 1, 3).

67 Ver Jörs y Kunkel (1937) p. 336.

68 Sobre esto puede consultarse Alessandri Rodríguez, (II-1), n. 42, p. 231 y De la Maza (2010). Ver, además, Supermercado de Materiales de la Construcción Limitada contra Empresa Constructora de Viviendas Económicas Diez, Luengo, Weil (2010).

69 Ver Alessandri Rodríguez (2003 c) p. 213, y más actualmente, Oviedo (2010) p. 262.

70 Flores Marta con Pérez Eulogio (1988).

71 Desde luego esta es una conjetura, pero no una demasiado aventurada. Se trata de un incumplimiento que, por su gravedad, satisface el carácter resolutorio del incumplimiento. Sobre la gravedad del incumplimiento como requisito de la resolución puede consultarse MEjías (2011).

Todo lo anterior en el entendido en que no se trate de circunstancias que configuren el supuesto de hecho de la evicción. Al margen de lo que se dirá más adelante sobre evicción, existe un caso en el que el comprador de un automóvil alega resolución por incumplimiento de la obligación de entrega toda vez que fue obligado a entregar dicho vehículo a la Aduana de Antofagasta en virtud de una incautación emanada del Tribunal Aduanero. Añadió que la empresa vendedora tampoco había cumplido con su obligación de ampararlo en la posesión pacífica de la cosa vendida. La empresa vendedora contestó señalando que había cumplido con su obligación de dar pues esta era de ejecución instantánea. Añadió que las normas sobre evicción no podían emplearse en este caso pues eran incompatibles con las de resolución. Por su parte, el tribunal de letras de Antofagasta no dio lugar a la acción reso- 
Despejada la diferencia entre vicios redhibitorios y aquellos que no lo son, resta la pregunta acerca de si la presencia de vicios redhibitorios permite al comprador acudir al régimen general de remedios.

A este respecto será útil comenzar recordando la sentencia de la Corte Suprema de fecha 27 de julio de $2005^{72}$ en cuyo considerando sexto la Corte Suprema consideraba, conviene recordarlo, que:

En consecuencia, la situación se traduce en que, ante el cumplimiento imperfecto de la obligación de entregar, puede suceder que se reúnan los requisitos de los vicios ocultos, en cuyo caso se aplican las normas del párrafo $8^{\circ}$ del Título XXIII del Libro Cuarto del Código Civil, pero si no se dan dichas exigencias puede reclamarse el cumplimiento de la obligación de entregar por parte del vendedor, a través del artículo 1.489 del Código Civil, si concurren los presupuestos que exige la norma, dando lugar así a la aplicación de la condición resolutoria tácita de este precepto de aplicación general.

Aparentemente, entonces, lo que la Corte parece querer decir es que si se satisfacen los requisitos del régimen de los vicios redhibitorios -y en ese caso no se satisfacían- el comprador debe acudir a los remedios que le prodiga dicho régimen.

El siguiente ejemplo avanza en la misma línea. Se discute, a propósito de la venta de unos departamentos, el plazo de prescripción de la acción indemnizatoria del artículo 1.861. Sin embargo, a efectos de este trabajo no es ese tema el que interesa, sino las reflexiones de la Corte de Apelaciones de San Miguel, en una sentencia de 27 de enero de $2006^{73}$, respecto de la convivencia del régimen general de remedios frente al incumplimiento contractual y el régimen de remedios propios del saneamiento por vicios redhibitorios. En palabras del Tribunal:

no cabe asimilar la obligación de saneamiento de los vicios redhibitorios, a una obligación derivada exclusivamente del objeto del contrato de compraventa, esto es una o más cosas que se trata de dar hacer o no hacer, según conceptúa el art. 1.460 del Código Civil, básicamente en este caso, las correlativas de entrega o tradición de la cosa y el pago del precio, de modo que su incumplimiento pudiere llegar a constituir la condición resolutoria tácita del art. 1.489 del mismo cuerpo legal, por cuanto el saneamiento de los vicios llamados redhibitorios está tratado especialmente en dicho Código y proporciona una acción distinta a la resolutoria, llamada redhibitoria, que como su nombre indica, redhibir puede llevar al comprador a deshacer la venta según el derecho por no haberle manifestado el vendedor el defecto o gravamen de la cosa vendida (Diccionario de la Real Academia). Estos vicios en nuestro Código

lutoria pues consideró que la entrega material y jurídica había tenido lugar y que ese tipo de problemas era propio del régimen de la evicción, sin embargo, para activarlo resultaba necesaria la citación del vendedor, cuestión que en la especie no había sucedido. Fernando Alejandro Vega Ríos c. Sociedad Codimar Limitada (2003).

72 Ver n. 50.

73 Mario Jara Carrasco y otros con San Francisco Limitada (2006). 
Civil, generan una acción diferente al comprador para que se deshaga (dice rescinda) la venta o para que se rebaje proporcionalmente el precio, según los artículos 1.857 y siguientes. Ello está referido a la causa que lo llevó a contratar de la manera como lo hizo, toda vez que este es el motivo que induce al acto o contrato, según el art. 1.467 del mismo Código.

De tal modo que ni siquiera un incumplimiento del saneamiento ni la indemnización de perjuicios que de ello se podría derivar, permite asimilar la acción deducida a una resolutoria tácita y su consecuente indemnización que autoriza el art. 1.489 del Código Civil, ya que el asunto es causal de una acción diferente, expresamente regulada en la compraventa que pudo o no ejercerse y que incluso los contratantes pudieron haber ampliado o restringido en su contrato (arts. 1.859 , 1.863 y 1.866 del mismo Código) pero que en el caso de autos resultó ser solo la de rebaja del precio y la consiguiente indemnización de sus eventuales perjuicios derivados de haberse pagado un precio estimado excesivo.

Aunque la Corte de Apelaciones no indica expresamente cómo ha de resolverse en concurso señala que no resulta posible asimilar las obligaciones de saneamiento con las obligaciones cuyo incumplimiento da lugar a la acción resolutoria. Esta afirmación puede leerse en dos sentidos diversos. El primero es que simplemente no se produce concurso pues el supuesto de hecho de las acciones edilicias difiere de aquel propio de la acción resolutoria. El segundo sentido consiste en afirmar que, aun cuando se acepte el concurso, este se resuelve por un desplazamiento del régimen general por la disciplina de las acciones edilicias.

Pues bien, como se ve, este par de fallos apunta a una tendencia según la cual, tratándose de circunstancias que configuran a la vez el supuesto de hecho de las acciones edilicias y de la acción resolutoria, debe preferirse el régimen propio de los vicios redhibitorios.

Sin embargo, esta tendencia no resulta consistente con otros grupos de fallos en los cuales los tribunales de justicia han resuelto cuestiones similares acudiendo, indistintamente, al régimen propio de las acciones edilicias y al régimen general de remedios.

El primer grupo de casos se refiere a vicios en la construcción. Así, por ejemplo, en una sentencia de la Corte Suprema de 27 de marzo de $2008^{74}$ en la cual la demandante considera ciertos vicios de la construcción respecto de los ductos de ventilación como redhibitorios y solicita la correspondiente indemnización del artículo 1.861. La Corte Suprema lo acoge. En otro caso, sin embargo, la Corte de Apelaciones, en una sentencia de 5 de septiembre de $2001^{75}$ accedió a la pretensión resolutoria del demandante frente a los defectos de construcción que afectaban al inmueble adquirido. En igual sentido puede consultarse la sentencia de la Corte de Apelaciones de Rancagua de 4 de septiembre de $2007^{76}$ y la sentencia de la Corte Suprema de 20 de abril de $2010^{77}$ en la cual se tiene por acredi-

\footnotetext{
74 Rosario Larzabal Beraza con Sociedad Inmobiliaria Talasia Limitada (2008).

75 Medina Rojas, Alejandro E. con Natural Home S.A. (2001).

76 Henríquez Durán, Carlos y otro (2007).

77 Bustos Muñoz, Ricardo cl Inmobiliaria Fourcade S.A. (2010).
} 
tado que la casa habitación objeto de la litis adolecía de imperfecciones, defectos de construcción y equipamiento y se da lugar a la solicitud cumplimiento forzado del demandante.

Algo similar parece suceder en un segundo grupo de casos configurado por ventas de automóviles defectuosos. Así, por ejemplo, la sentencia de la Corte Suprema de 25 de julio de 2007 acoge la demanda indemnizatoria derivada de la presencia de vicios redhibitorios en un vehículo ${ }^{78}$. Por su parte, la sentencia de 19 de noviembre de 2009 de la Corte Suprema $^{79}$ declaró la resolución de un contrato de compraventa de un automóvil debido a los defectos que presentaba señalando:

Que la demandante en su actuar ha obrado desde el momento de la adquisición del vehículo con buena fe, pues recurrió a la demandada a que le solucionaran los desperfectos del vehículo vendido, empero, la camioneta después de cinco reparaciones no puede entenderse que tenga un defecto de fábrica que solo con una reparación se solucione.

Que por todo lo antes razonado y de acuerdo al artículo 1.489 del Código Civil que establece la institución de condición resolutoria tácita, la sentenciadora declarara resuelto el contrato, por lo que las cosas deberán restituirse recíprocamente entre las partes. En cuanto a la restitución del vehículo, dicho trámite se obviara, toda vez que la especie se encuentra en poder de la demandada.

Pues bien ¿qué puede desprenderse de lo que va dicho sobre vicios redhibitorios?

En primer lugar, una obviedad y es que se trata de un incumplimiento que posee su propio régimen de remedios el que, sin embargo, únicamente se aplica cuando se trata de defectos intrínsecos de la cosa referidos a su materialidad.

El carácter relativamente obvio de esta primera consideración debería tornar obvia la respuesta a la pregunta acerca de qué obligación se incumple y cuáles son sus remedios. Sin embargo no es así. Y conviene considerar por qué no.

Ante todo ¿en qué sentido puede afirmarse que se incumple la obligación de saneamiento? Carrasco Perera, ha señalado que, en rigor, la entrega de una cosa defectuosa no constituye incumplimiento contractual "sino una contingencia que hace nacer en el vendedor una obligación secundaria de sanear este defecto mediante la devolución de la cosa o la rebaja del precio" 80 . Además, como ha quedado dicho, el funcionamiento de las acciones edilicias no se asemeja a un deber, sino que constituye una garantía ${ }^{81}$.

En segundo lugar, tampoco resulta sencilla la respuesta a la pregunta respecto a qué remedios dispone el comprador frente a la presencia de vicios redhibitorios. Desde luego, dispone de los remedios propios de esta especie de vicios. Sin embargo, la pregunta más acuciante es si, además, dispone de los propios del régimen general. Y aquí la respuesta no

\footnotetext{
78 Aquiles Spataris Schaffhauser con Sociedad Comercial Automotriz La Portada; Alejandro Luna Casas (2005).

79 Comercial Automotriz Quilin Limitada contra Ide Sanzberro, Julián (2009).

80 Carrasco (2010) p. 41.

81 Con todo, algunos autores españoles han considerado inadecuado el uso de la expresión "garantía" a estos efectos, toda vez que la garantía tendría una función preventiva de la que el saneamiento carece; el saneamiento tendría una función reparatoria. Ver Rubio (1993) p. 499 y Durán (2002) pp. 58-60.
} 
es clara. Como ya ha quedado dicho, de algunas sentencias parece desprenderse que no, o bien porque no se presenta concurso o bien porque presentándose la regla especial deroga a la general. Sin embargo, en otros casos (los vicios de la construcción y los defectos en automóviles) los tribunales parecen haber aceptado, indistintamente, que el comprador recurra a las acciones edilicias o bien a los remedios del régimen general.

\subsection{Venta de cosa AJEnA}

Mi interés respecto de la venta de cosa ajena consiste en investigar es si esta especie de venta, aún sin que el verdadero dueño ejerza sus derechos en contra del comprador ${ }^{82}$, puede constituir un incumplimiento de la obligación del vendedor. Para enfrentarla convendrá comenzar con algunas precisiones.

La primera, me parece a mí, es que, según lo dispuesto en el artículo 1.815, la venta de cosa ajena es válida. Esto, sin embargo -y como lo dispone el mismo precepto-, sin perjuicio de los derechos del verdadero dueño. Por lo tanto, también debe resultar pacífico que si la cosa se entregó al vendedor y esto resulta posible, el verdadero dueño puede ejercer en contra del comprador las acciones que amparan su derecho de dominio. Si decide hacerlo, también ha de resultar pacífico que el comprador dispone de las acciones propias del saneamiento por evicción según las reglas pertinentes.

La cuestión del incumplimiento, entonces, no se presenta respecto del saneamiento sino de la obligación de entrega y la pregunta ha de ser si esta se incumple cuando el vendedor no es dueño de la cosa.

La segunda precisión se relaciona con el hecho de que el comprador haya o no asumido el riesgo del dominio ajeno. La situación más desafiante, desde luego, se presenta si no lo ha asumido ${ }^{83}$.

La tercera precisión se refiere al hecho de que la entrega haya tenido lugar o no. Si no ha tenido lugar y ya es debida nos encontramos frente a una falta de entrega y, no cabe duda, habrá incumplimiento.

La verdadera cuestión parece presentarse cuando el comprador no ha asumido el riesgo del dominio ajeno y la cosa se le ha entregado. El problema aquí consiste en determinar si puede hablarse de una entrega defectuosa que, al margen de las normas sobre evicción, configure incumplimiento contractual. Para ponerlo en términos más sencillos, la pregunta, generalmente, será si el comprador puede resolver el contrato por incumplimiento.

Como resulta evidente, la respuesta ha de depender del contenido de la obligación del vendedor, particularmente habrá que precisar si el vendedor se obligó o no a transferir el dominio. Si la respuesta es que sí, entonces habrá que concluir que únicamente la tradición dominical satisface la obligación de entrega. Si la respuesta es negativa, la conclusión es que incluso una tradición a non domino satisface dicha obligación.

Planteadas las cosas de esta manera, la respuesta debiese ser sencilla porque, como señala Alessandri: "[Nuestro Código] (R)eprodujo (...) la regla romana, según la cual el

\footnotetext{
82 Me refiero a ese supuesto en el número siguiente.

83 Si en el contrato se ha dejado constancia de que la cosa no pertenece al vendedor, no resulta posible -salvo que se haya obligado a adquirir el dominio- alegar incumplimiento por este hecho.
} 
vendedor se obliga a poner al comprador en posesión tranquila y pacífica de la cosa vendida de modo que, entre nosotros, aquel no se obliga a dar la propiedad al comprador" ${ }^{84}$. Esta posición, según señala UGARTE, ha sido "abrumadoramente mayoritaria" en Chile ${ }^{85}$. Entonces, la respuesta habría de ser que, en la medida en que el vendedor no se ha obligado a transferir la propiedad, no ha incumplido con su obligación de entrega cuando la cosa no le pertenece. Cuestión distinta es que si el comprador es perturbado en su posesión pacífica dispondrá de la protección que le prodiga el régimen de la evicción.

Sin embargo, como suele suceder, la respuesta es menos nítida de lo que aparece en el párrafo anterior. De una parte UGARTE ha considerado que la transferencia de la propiedad constituiría una obligación esencial del vendedor ${ }^{86}$. Sin embargo, no obstante el ingenio de sus argumentos, probablemente, planteada de esa manera, la tesis resulte incorrecta porque, como ha sugerido Díez-Picazo respecto del Código Civil español -en términos perfectamente extrapolables al chileno-

...no hay rastro en el Código de una específica obligación de transmitir la propiedad, que determine un incumplimiento contractual -con todas las consecuencias que el incumplimiento acarrea- en los casos en que el vendedor que ha entregado una cosa, no transmita el dominio de ella. El vendedor cumple su compromiso si proporciona al comprador una posesión quieta y pacífica y, además, se la garantiza ${ }^{87}$.

Pero aún sin compartir la posición del profesor Ugarte, conviene advertir que las afirmaciones de Alessandri no responden completamente a la pregunta acerca de si el vendedor está obligado a transferir el dominio. Para entender por qué habrá que volver al artículo 1.824, según cuyo tenor, en lo pertinente: "Las obligaciones del vendedor se reducen en general a dos: la entrega o tradición, y el saneamiento de la cosa vendida". El punto está en el uso de la expresión "en general" y aquí conviene considerar de nuevo la opinión de Alessandri. Según este autor:

Las obligaciones propias del vendedor y que nacen del contrato de venta por el solo efecto de celebrarse sin necesidad de que las partes, es decir, las obligaciones que la ley impone son dos: la entrega de la cosa y el saneamiento de la misma. Sin perjuicio de ellas, los contratantes pueden estipular otras o atenuar o modificar esas dos. En tal caso deben pactarse expresamente, pues, a falta de tal convenido, el vendedor no tiene sino las señaladas por la ley y en la extensión que esta establece ${ }^{88}$.

Pues bien lo que ha quedado señalado en el párrafo anterior es que si las partes nada dicen acceden sin necesidad de pacto expreso al contrato de compraventa las obligaciones

\footnotetext{
84 Alessandri (2003 b) p. 659.

85 Ugarte (1970) p. 151.

86 UGarte (1970).

87 Díez-Picazo (2010) p. 58.

88 Alessandri (2003 b) p. 573.
} 
de entrega y saneamiento. Sin embargo, la autonomía privada de las partes puede actuar en dos direcciones, introduciendo otras obligaciones o modificando aquellas que acceden naturalmente al contrato. Entonces, resulta posible afirmar que, sin el pacto de las partes, la obligación de entrega se satisface con un traspaso posesorio. La pregunta habrá de ser más bien si, a través del ejercicio de su autonomía privada, las partes pueden modificar esta circunstancia determinando que únicamente se satisfaga la obligación de entrega con una tradición dominical.

La respuesta, en mi opinión, ha de ser afirmativa. Parece evidente que, al menos en ciertas ocasiones (probablemente en la mayoría de ellas) el interés del comprador no quedará satisfecho si no se le transfiere la propiedad de la cosa ${ }^{89}$. Por otra parte, como anota Alessandri, el carácter dispositivo que solemos reconocer a las reglas de contratos imprime suficiente ductilidad a la norma del artículo 1.824 y no se advierten razones de orden público para sospechar de la licitud de un pacto como este. Por estas razones, habrá que estar de acuerdo con la opinión de Díez-Picazo según la cual:

Ninguna duda suscita la posibilidad de que la obligación de transmitir la propiedad se establezca mediante un convenio expreso, que pueda, además, ir acompañado de un pacto resolutorio expreso para el supuesto de que tal obligación no se llegue a ejecutar ${ }^{90}$.

Ahora bien, siguiendo con DíEz-Picazo, podría formularse la cuestión en términos más ambiciosos y preguntarse si resulta posible considerar incumplimiento la entrega de una cosa ajena aun en aquellos casos en los que no se ha pactado expresamente la transferencia del dominio. En términos perfectamente extrapolables para el ámbito nacional, este autor señala que si bien es cierto que la regulación de la compraventa no impone la obligación de transferir el dominio no existe obstáculo para que dicha obligación se integre al contrato con cargo al artículo 1.258 del Código Civil español ${ }^{91}$ cuyo tenor es el siguiente: "Los contratos se perfeccionan por el mero consentimiento, y desde entonces obligan, no solo al cumplimiento de lo expresamente pactado, sino también a todas las consecuencias que, según su naturaleza, sean conformes a la buena fe, al uso y a la ley”. A partir de dicho precepto concluye:

No existe base, en nuestro Derecho positivo, para entender que en todo contrato de compraventa se produzca una obligación de transmitir la propiedad por imperio de la buena fe contractual. Sin embargo, de ello no se puede deducir que, por lo menos en algunos casos, la buena fe no imponga esa obligación. La cuestión es entonces determinar en qué casos puede inducirse que existe, como consecuencia de la buena fe, la obligación de transmitir la propiedad. A nuestro juicio, es posible encontrar por lo menos dos supuestos. Si no se olvida que la buena fe se encuentra muy relacionada

\footnotetext{
89 Piénsese, por ejemplo, si desea darla en garantía o si deseaba comerciar con la cosa.

90 Díez-Picazo (2010) pp. 60-62.

91 Díez-Picazo (2010) p. 58.
} 
con la confianza que las declaraciones de voluntad y los comportamientos concluyentes suscitan, habrá que entender que el vendedor tiene, por buena fe, obligación de transmitir la propiedad, si le constaba o debía constarle, que el comprador había actuado sobre la base de la confianza en adquirir el dominio. Creemos que existe también obligación contractual de transferir la propiedad en todos aquellos supuestos en que al vendedor le conste, o deba constarle, que las finalidades económicas pretendidas por el comprador solo pueden conseguirse convirtiéndose en propietario de la cosa comprada ${ }^{92}$.

Ahora convendrá volver a la pregunta formulada más arriba ¿constituye incumplimiento de la obligación de entrega la venta de cosa ajena en los términos planteados? La respuesta debe ser que depende. Y depende de lo que el contrato, debidamente integrado por las exigencias de la buena fe, exija al vendedor. Ante todo, si este se ha obligado expresamente a una tradición dominical únicamente a través de ella cumplirá. Si este no ha sido el caso habrá que distinguir según si la buena $\mathrm{fe}^{93}$ protegía las expectativas del comprador de transformarse en dueño por la tradición. Una recepción amplia, como la que ha tenido este principio entre nuestros autores y tribunales superiores ${ }^{94}$ indica que los supuestos identificados por Díez-Picazo también podrían recibir aplicación en Chile.

\subsection{La EVICCión}

Aceptar para el ordenamiento jurídico nacional una respuesta respecto de la venta de cosa ajena como la de Díez-Picazo exige dar una mirada a la forma en que opera el saneamiento por evicción.

Esta mirada, sin embargo se encuentra circunscrita en el mismo sentido en que limité mi aproximación a los vicios redhibitorios. La pregunta que interesa considerar es si el régimen de la evicción -que es aquel que en el Código Civil protege la posesión pacífica del comprador y que, al igual que las acciones edilicias funciona como garantía- desplaza o no la posibilidad de acudir al régimen general de remedios. Planteadas las cosas de otra manera, interesa investigar si, como sucedía en el régimen de los vicios redhibitorios, puede plantearse aquí un concurso entre las acciones propias de la evicción y aquellas del régimen general y, si la respuesta es afirmativa, cómo ha de solucionarse.

Para examinar esta cuestión convendrá comenzar por la sentencia de la Corte de Apelaciones de Valdivia de 16 de noviembre de $2009^{95}$. Los hechos ya han sido sucintamente descritos, de manera que es posible continuar con los considerandos relevantes.

El tribunal de primera instancia entiende que se ha producido un incumplimiento del contrato por las perturbaciones de hecho y de derecho que sufre el comprador pues, en opinión de la juzgadora:

\footnotetext{
92 Díez-Picazo (2010) pp. 58-59.

93 Para estos efectos el artículo 1.546 del Código Civil chileno resulta perfectamente comparable con el artículo 1.258 de su par español.

94 Sobre ambas cosas puede consultarse Boetsch (2011) pp. 137-156.

95 Ver n. 64.
} 
“...se trata de una obligación de dar, que no se limita a la transferencia jurídica del predio, sino que también comprende las facultades de uso y goce del mismo, lo que no aconteció, dado que al comprador se le impidió hacerlo por la existencia de terceros en el lugar, hecho que no era desconocido para el vendedor".

La Corte de Apelaciones de Valdivia, sin embargo, no comparte esta opinión. Comienza señalando que los hechos acreditados en el proceso no configuran un incumplimiento contractual que, directamente, pueda dar lugar a una indemnización de perjuicios. Argumenta el Tribunal que el vendedor no se obliga a hacer dueño al comprador, sino proporcionarle una posesión pacífica y útil. Luego añade que:

“...si jurídicamente no constituye incumplimiento contractual (de la obligación de entregar en la compraventa) el hecho de que todo el objeto del contrato (la totalidad del predio, en la especie) resulte ser de dominio ajeno, entonces, a fortiori, menos puede serlo la circunstancia de que una sección menor del mismo sea objeto de disputa dominical, como ocurre en la especie".

Señala que, en esos casos, las reglas pertinentes para solicitar la indemnización son las propias del régimen de la evicción y añade que si hubiese un conflicto entre las normas generales indemnizatorias y las propias de la evicción "Lex specialis derogat legi generali".

Finalmente, sobre la forma de resolver de la juzgadora de primera instancia la Corte considera:

Que no entenderlo así, como hace la sentencia de primer grado, produce una importante distorsión del completo sistema de obligaciones contractuales y remedios legales frente a incumplimientos derivados del contrato de compraventa de inmuebles, al margen de afectar de modo decisivo el principio de conservación del negocio jurídico. En efecto, comprender la regulación legal de ese sistema de obligaciones y remedios del modo como lo ha hecho la sentencia en alzada supone alterar la voluntad legislativa, a la cual deben imperativo acatamiento los jueces, en al menos los siguientes puntos. Primero, altera la regla invariable de que el alcance de la obligación de entregar se refiere a la posesión y no al dominio, permitiendo que se deje sin efecto el contrato y se pida indemnización de perjuicios (y aun, como hace la sentencia en alzada, solo lo segundo, independizando la indemnización de la resolución o el cumplimiento forzado) cuando existan cuestionamientos dominicales, aun parciales, sobre la cosa. Segundo, hace meramente optativa para el comprador la obligación legal imperativa del artículo 1.843 del Código Civil, que estipula que "el comprador a quien se demanda la cosa vendida, por causa anterior a la venta, deberá citar al vendedor para que comparezca a defenderla" y desoye el mandato legal del inciso tercero de ese mismo artículo que dispone que "si el comprador omitiere citarle, y fuere evicta la cosa, el vendedor no será obligado al saneamiento; y si el vendedor citado no compareciere a defender la cosa vendida, será responsable de la evicción; a menos que el comprador haya dejado de oponer alguna defensa o excepción suya, y por ello 
fuere evicta la cosa”. Esa disposición legal, como se ve, exime de responsabilidad al vendedor que no es citado de evicción...

Considera el tribunal de primera instancia que, en los hechos, ha existido un incumplimiento resolutorio pues la entrega, digámoslo así, involucra una posesión pacífica. La Corte, en tanto, opina de manera diversa. Estima que el hecho de que la tradición no sea dominical o la existencia de derechos de terceros no constituye incumplimiento de la obligación de entrega, sino el supuesto del régimen de la evicción. Parece aceptar que existe posibilidad de concurso entre los remedios propios de la evicción y el régimen general, pero no duda que la solución en ese caso es que la regla especial deroga a la general, Lex specialis derogat legi generali. Entenderlo de otra manera, estima el Tribunal sería tornar operativa una regla -la del 1.843- que posee carácter imperativo.

Como se ve la sentencia es particularmente clara, el régimen de la evicción desplaza al de los remedios generales. Sin embargo, esa claridad tiende a obscurecerse si se confronta este fallo con la sentencia de la Corte de Apelaciones de Concepción de 1 de diciembre de $1993^{96}$. Una vez más, los hechos ya han sido descritos, de manera que se puede seguir directamente a los considerandos pertinentes. Señala la Corte:

70. Que el Código Civil impone al vendedor la obligación de entrega de la cosa vendida y la de garantía de que ella no contiene vicios ocultos, así como la de responder de su evicción, según los artículos 1.824 y 1.837. Por su parte, la obligación de entregar implica entre nosotros, tanto la de hacer la tradición, como la de pasar materialmente la cosa a poder del comprador. Pero lo que el vendedor ha de entregar es la misma cosa que se individualiza en el contrato y esa obligación solo se cumple si lo entregado es la cosa tal y como ha sido convenida, de forma que, faltándole alguna parte o afectándole algún derecho en favor de un tercero que pueda producir su evicción, el vendedor no ha cumplido cabalmente su obligación;

$8^{\circ}$. Que, si bien el Código Civil distingue la obligación de entregar de la de saneamiento de la evicción, ello no ha de llevar a la conclusión que se trate de obligaciones absolutamente desligadas, de forma que, habiéndose hecho la tradición y la entrega material, esté cumplida la primera y que todo derecho existente en favor de terceros sobre la cosa sea objeto únicamente de la obligación de saneamiento de la evicción.

En efecto, como lo sostienen autorizados doctrinadores, si la cosa vendida está gravada con cargas o si existen derechos de terceros o aun si la cosa es ajena, la obligación de saneamiento se hace efectiva desde que el tercero reclame su derecho, en tanto que, mientras ello no suceda, si el comprador advierte la existencia de tales derechos, aunque no reclamados por su titular, puede prevalecerse de las acciones a que da lugar el cumplimiento de la obligación de entregar (así, F. Messineo, Manual de Derecho Civil y Comercial, t.5 n. 18, pág. 98). Esa conclusión, que otras legislaciones han pormenorizado en reglas explícitas (por ejemplo, artículo 1.489 Código Civil

96 Ver n. 58. 
italiano), es también la que resulta de las normas de nuestro Código, si se tiene presente lo prevenido en los artículos 1.828, 1.838, 1.843 y 1.489 del Código Civil.

(...)

En las palabras de eminentes autores, cuando la compraventa recaiga sobre un cuerpo cierto, el vendedor está obligado igualmente a entregar la cosa tal y como ha sido convenida, querida por las partes; en consecuencia, si la cosa vendida y entregada está afectada por un vicio oculto, ignorado por el comprador, o si lleva consigo una posibilidad de evicción, el vendedor no ha cumplido con su obligación de entrega (H.L. y J. Mazeaud, Lecciones de Derecho Civil, parte 3, vol., n. 937). Pero una vez que un tercero se adelante a reclamar derechos sobre la cosa por causa anterior a la venta, surge para el vendedor la obligación de defensa y saneamiento. La distinción entre ambas obligaciones es pues más de oportunidad que de diferencia de contenido y es lo que explica en modernas tendencias, se unifiquen ambas en la de entregar. Así entonces, desde que las partes convinieron en que el departamento once de calle Infante 145 de la ciudad de Penco se vendía libre de gravámenes y prohibición, la vendedora no cumplió con exactitud su deber de entregar lo que reza el contrato, desde que ese inmueble estaba afecto a una hipoteca y una prohibición en favor del Banco del Estado, según se ha dicho más arriba”.

Ante todo, la Corte de Apelaciones de Concepción, haciendo pie en autorizada doctrina, estima que la existencia de derechos de terceros no es una cuestión que quede confinada exclusivamente al régimen de la evicción, sino que, eventualmente, será objeto de alguna acción propia del régimen general de remedios.

Ahora bien, una opinión como esa parece frontalmente contradictoria con la de la sentencia de la Corte de Apelaciones de Valdivia, y en algún sentido lo es. Sin embargo, la contradicción puede resultar menos rotunda de lo que a primera vista aparece. En realidad, la sentencia de la Corte de Apelaciones de Concepción no se pronuncia, como sí hace la de la Corte de Valdivia, sobre el concurso entre las acciones de la evicción y los remedios generales. La razón es que la sentencia de la Corte de Concepción se refiere a la posibilidad de intentar las acciones propias del régimen general de remedios antes de que el tercero haya intentado alguna acción en contra del comprador, por lo tanto, antes de que sea posible el ejercicio de las acciones propias de la evicción. Sin embargo, nada dice respecto al momento en que ya se intentaron esas acciones y es a ese momento al cual está dedicada la sentencia de la Corte de Apelaciones de Valdivia.

Por lo tanto -aunque forzando levemente las cosas- pueden conjugarse ambas sentencias estimando que, antes del ejercicio de las acciones de terceros, el comprador puede servirse del régimen general de remedios para alegar el incumplimiento de la obligación de entrega cuando existan derechos de terceros. Una vez que la acción intentada por el tercero ha sido notificada al comprador, aparentemente, este únicamente puede servirse de las acciones propias del régimen de la evicción ${ }^{97}$.

97 En este sentido puede consultarse José Hilario Arriagada Sepúlveda; con Ricardo Fernández Toloza (2002) y Sin identificación de partes (1990). 


\section{A MANERA DE CONCLUSIÓN: EL RÉGIMEN DE LOS CUMPLIMIENTOS DEFECTUOSOS, PROBLEMAS Y PERSPECTIVAS}

En primer lugar habrá que concluir que los cumplimientos defectuosos pueden incardinarse ya sea en el incumplimiento de la obligación de entrega o bien a propósito de los saneamientos. Así, por ejemplo, los defectos de cabida quedan comprendidos como un incumplimiento de la obligación de entrega; igual cosa sucede con los vicios jurídicos o con los derechos de terceros antes de la notificación al comprador. En cambio, como resulta evidente, se incardinan en la disciplina del saneamiento aquellos incumplimientos cuyos supuestos de hecho corresponden al régimen de la evicción o de los vicios redhibitorios.

En segundo lugar, en un sistema ordenado, la incardinación de los cumplimientos defectuosos en la obligación de entrega o en la de saneamiento, debiese establecer algún correlato simétrico respecto de los remedios, en términos tales que los incumplimientos de la obligación de entrega quedarán sujetos al régimen general de remedios y los de la obligación de saneamiento a os remedios propios de estos regímenes. Sin embargo, esto no sucede, no sin fricción al menos. Por dos razones al menos.

La primera razón, según me parece, es que los supuestos de hecho de los saneamientos no pueden diferenciarse nítidamente ni del supuesto de hecho de las acciones propias del régimen general de remedios ni de las propias de las acciones de nulidad por vicios del consentimiento (específicamente error y dolo). En otras palabras, en estos casos puede presentarse concurso entre acciones generales y especiales o entre cualquiera de ellas y las de la nulidad por vicios del consentimiento.

La segunda razón es que al momento de resolver ese concurso las opiniones de los tribunales no resultan consistentes porque -al menos tratándose del concurso entre acciones generales y especiales- su forma de comprender la obligación de entrega no es consistente. Para algunos esta obligación se satisface con la entrega material y jurídica. Para otros, en cambio, debe tratarse de una entrega que satisfaga el interés del comprador protegido por el contrato. En este sentido, el uso de la doctrina del aliud pro alio en su versión funcional puede vaciar de contenido la regulación de la cabida, la evicción y los vicios redhibitorios.

En tercer lugar, una situación como la descrita resulta problemática en dos sentidos al menos. El primero de ellos se refiere a la justificación del diseño de las normas ¿qué explica la subsistencia de regímenes especiales en el Título de la compraventa? ¿Por qué se protege de manera diversa a quien compra un predio rústico de quien compra uno urbano, o bien a quien compra una cosa con un defecto jurídico de quien compra una cosa con un defecto físico? En fin ¿por qué se priva a quien es demandado por el verdadero dueño de la acción resolutoria propia del régimen general? Mi sospecha es que no existen respuestas persuasivas que justifiquen esta diferencia, sino nada más la pesada inercia de los siglos. A este respecto Morales Moreno, está en lo correcto cuando advierte que la razón que justifica un régimen especial de remedios por vicios redhibitorios -y podríamos añadir la evicción y los problemas de cabida- es únicamente histórica y no se explica, en cambio, como “...una exigencia de un adecuado tratamiento del problema" ${ }^{8}$.

98 Morales (2006 b) p. 98. 
Sin embargo, la imposibilidad de justificar la forma en que se organizan los remedios de que dispone el comprador tratándose de cumplimientos defectuosos no es el único -ni el principal- problema. La situación resulta problemática en un segundo sentido y es la falta de certeza jurídica que impone el hecho de que los tribunales no consideren de manera consistente el alcance de la obligación de entrega.

En cuarto lugar, los dos problemas descritos aconsejan repensar el régimen de los cumplimientos defectuosos. Mi opinión es que en esta tarea se dispone, a nivel de derecho comparado, de un valiosísimo material en los desarrollos legislativos, de soft law y dogmáticos que han tenido lugar a partir de la Convención de Viena sobre Compraventa Internacional de Mercaderías ${ }^{99}$. Ese, sin embargo, debería ser el objeto del próximo trabajo.

\section{BIBLIOGRAFÍA}

Abeliuk Manasevich, René (2008): Las obligaciones, t II, 5a ed. (Santiago Editorial Jurídica de Chile), 1293 pp.

AlCalde Silva, Jaime (2008): “El commodum repraesentationis del artículo 1677 del Código Civil de Chile", en Revista de Derecho de la Pontificia Universidad Católica de Valparaíso XXX, pp. 37-161.

Alessandri Rodríguez, Arturo (2003 a): De la compraventa y de la promesa de venta, t. I, vol. 1 (Santiago Editorial Jurídica de Chile), 465 pp.

Alessandri Rodríguez, Arturo (2003 b): De la compraventa y de la promesa de venta, t. I, vol. 2 (Santiago Editorial Jurídica de Chile) 931 pp.

Alessandri Rodríguez, Arturo (2003 c): De la compraventa y de la promesa de venta, t. II, vol. 1 (Santiago Editorial Jurídica de Chile), 556 pp.

Alessandri Rodríguez, Arturo (1917): De La Compra Venta I De La Promesa De Venta (Santiago, Imprenta Litografía Barcelona).

Barros Bourie, Enrique (2006): Tratado de responsabilidad extracontractual (Santiago Editorial Jurídica de Chile) 1230 pp.

Boetsch Gillet, Cristián (2011): La buena fe contractual (Santiago, Abeledo Perrot) 220 pp.

Carrasco Perera, Ángel (2010): Derecho de contratos (Cizúr Menor, Navarra, Thomson Reuters) 1319 pp.

Corral Talciani, Hernán (2010): "Concurrencia de acciones de responsabilidad civil contractual y extracontractual en los daños causados por accidentes del trabajo”, en Revista Chilena de Derecho Privado, no 14, pp. 69-107.

De la Maza Gazmuri, Iñigo (2011): "El concurso entre el error con trascendencia anulatoria y el incumplimiento resolutorio", en ID. (ed.) Incumplimiento contractual: nuevas perspectivas, Cuadernos de Análisis Jurídicos, Colección de Derecho Privado VII (Santiago, U. Diego Portales), pp. 213-234.

De la Maza Gazmuri, Iñigo (2010): “A propósito del artículo 1.861”, en AA.VV., Estudios de derecho civil V Jornadas Nacionales de Derecho Civil Universidad de Concepción, 2009 (Santiago, Editorial Abeledo Perrot), pp. 455-470.

99 Sobre el tema puede consultarse Morales (2006 b) pp. 93-144. 
Díez-Picazo, Luis (2010): Fundamentos del Derecho Civil patrimonial, t. IV Las particulares relaciones obligatorias (Cizur Menor, Navarra, Thomson Reuters) 725 pp.

Díez-Picazo, Luis (2008): Fundamentos de Derecho Civil patrimonial, t. II Las relaciones obligatorias (Cizúr Menor, Navarra Thomson Civitas) 1092 pp.

Díez-Picazo, Luis, Roca Trías, Encarna, y Morales Moreno, Antonio Manuel (2002) Los principios del Derecho Europeo de los Contratos (Madrid Civitas), 529 pp.

Durán Rivacova, Ramón (2002): Evicción y saneamiento (Cizur Menor/Navarra, Aranzadi) $345 \mathrm{pp}$.

Elorriaga DE Bonis, Fabián (2002): "Ponencia principal", en AA.VV., Estudios sobre reformas al Código Civil y Código de Comercio, 2a parte (Santiago Editorial Jurídica de Chile), pp. 13-125.

Faure AbBad; Marianne (2003): Le fait générateur de la responsabilité contractuelle (París LGDJ) 546 pp.

Fenoy Picon, Nieves (2010): “La modernización del régimen del incumplimiento del contrato: Propuestas de la Comisión General de Codificación. Parte primera: Aspectos generales. El incumplimiento", en ADC 63-1, pp. 74-75.

Fenoy Picon, Nieves (1996): Falta de conformidad e incumplimiento en la compraventa. (Evolución del ordenamiento español) (Madrid Colegio de Registradores de la Propiedad y Mercantiles de España Centro de Estudios Registrales) 611 pp.

Fueyo LANeri, Fernando (2004): Cumplimiento e incumplimiento de las obligaciones, $3^{\mathrm{a}}$ ed. actualizada por G. Figueroa Yánez (Santiago, Editorial Jurídica de Chile) 650 pp.

Gatica Pacheco, Sergio (1959): Aspectos de la indemnización de perjuicios por incumplimiento contractual (Santiago Editorial Jurídica de Chile) 533 pp.

GuZMÁn Brito, Alejandro (2007): "Sobre la relación entre las acciones de saneamiento de los vicios redhibitorios y las acciones comunes de indemnización, con especial referencia a su prescripción” (opinión profesional), en Revista Chilena de Derecho Privado, no 9, pp. 95-120.

Jones, Gareth y Schlechtriem, Peter (1977): "Breach of Contract (Deficience in a Party's Performance)", en A. von Mehren, Arthur (ed.) International Encyclopedia of Comparative Law. Contracts in General, vol. VII, t. 2 (Lovaina/Boston, Mohr Siebeck/ Nijhoff Publishers), cap. 15, pp. 1-159.

Jörs, Paul y Kunkel, Wolfang (1937): Derecho privado romano, Trad. Prieto Castro, (Barcelona, Lábor) 503 pp.

Larenz, Karl (1966): Metodología de la ciencia del derecho (Barcelona Ariel).

López Santa María, Jorge (2005): Los contratos, Parte General, t. II (Santiago, Editorial Jurídica de Chile).

Mejías Alonzo, Claudia (2011): "El incumplimiento que faculta a resolver el contrato a la luz de las disposiciones del Código Civil”, en De la Maza, Iñıgo. (coord.), Incumplimiento contractual: nuevas perspectivas, Cuadernos de Análisis Jurídicos, Colección de Derecho Privado VII (Santiago, U. Diego Portales) pp. 213-234.

Morales Moreno Antonio Manuel (2011): “¿Es posible construir un sistema precontractual de remedios? Reflexiones sobre la Propuesta de Modernización del Derecho de Obligaciones y Contratos en el marco del Derecho europeo", en Albiez Dohrmann, 
Klaus. (dir), Derecho privado europeo y modernización del Derecho contractual en España (Barcelona, Atelier), pp. 400-422.

Morales Moreno, Antonio Manuel (2010): Incumplimiento del contrato y lucro cesante (Cizúr Menor/ Navarra, Thomson Reuters) 192 pp.

Morales Moreno, Antonio Manuel (2006): La modernización del derecho de obligaciones (Cizur Menor, Navarra Thomson Civitas) 353 pp.

Morales Moreno, Antonio Manuel (2006 a): "Evolución del concepto de obligación en derecho español”, en ID., La modernización del derecho de obligaciones (Cizur Menor, Navarra, Thomson Civitas) pp. 17-53.

Morales Moreno, Antonio Manuel (2006 b): "Adaptación del Código Civil al Derecho europeo: la compraventa, en Morales Moreno, AM., La modernización del derecho de obligaciones (Cizur Menor Navarra, Thomson Civitas) pp. 93-143.

Oviedo Albán, Jorge (2010): "Sobre el concepto de vicio redhibitorio en la compraventa. Análisis comparado de la jurisprudencia chilena y colombiana", Revista Chilena de Derecho, vol. 37-2, 2010, pp. 241-269.

Rubio Garrido, Tomás (1993): Contrato de compraventa y transmisión de la propiedad (Bolonia Publicaciones del Real Colegio de Bolonia) 657 pp.

Salvador Coderch, Pablo (1997): “Comentario artículo 79”, en Díez-Picazo, Luis (Dir.), La compraventa Internacional de Mercaderías. Comentario de la Convención de Viena (Cizúr Menor, Navarra) Thomson Civitas, pp. 635-657.

Ugarte Godoy, José Joaquín (1970): "La obligación esencial del vendedor de transferir el dominio", en Mac Hale, Thomas., y Del Valle, Jaime, Estudios en honor a don Pedro Lira Urquieta (Santiago Editorial Jurídica de Chile) pp. 151-193.

Verda y Beamonte, José Ramón (2009): Saneamiento por vicios ocultos. Las acciones edilicias, 2a ed. (Cizúr Menor, Navarra, Thomson Reuters) 390 pp.

Vidal Olivares, Alvaro (2011): "El Incumplimiento y los remedios del acreedor en la Propuesta de modernización del Derecho de Obligaciones y contratos español", en el Derecho de Obligaciones español", en Revista Chilena de Derecho Privado, no 16, pp. 243-302.

Vidal Olivares, Álvaro (2010): "El incumplimiento de obligaciones con objeto fungible y los remedios del acreedor afectado", en Pizarro, Carlos y VIdal, Álvaro: Incumplimiento contractual, resolución e indemnización de daños (Bogotá, Editorial Universidad del Rosario), pp. 137-207.

Vidal Olivares, Álvaro (2009): "El incumplimiento resolutorio en el Código Civil. Condiciones de procedencia de la resolución por incumplimiento", en Pizarro Carlos. Wilson (coord.), Estudios de Derecho Civil IV (Santiago LegalPublishing), pp. 347-369.

Vidal Olivares, Álvaro. (2006): La protección del comprador. Régimen de la Convención de Viena y su contraste con el Código Civil (Valparaíso Ediciones Universitarias de Valparaíso) $242 \mathrm{pp}$.

Zimmmermann, Reinhard (2008): El nuevo derecho alemán de las obligaciones (trad. Arroyo i Amayuelas, Esther) (Barcelona, Bosch) 282 pp. 


\section{JURISPRUDENCIA CITADA}

Aquiles Spataris Schaffhauser con Sociedad Comercial Automotriz La Portada; Alejandro Luna Casas (2005), Corte Suprema, 25 de julio de 2007 (rebaja de precio e indemnización de perjuicios por vicios redhibitorios) cita Westlaw CL/JUR/6009/2007.

Bustos Muñoz, Ricardo cl Inmobiliaria Fourcade S.A. (2010), Corte Suprema, 20 de abril de 2010 (Indemnización de perjuicios), Id. Microjuris MJJ23746.

Casa do Brasil Sociedad Limitada con Mall Puente S.A.(2008), la Corte de Apelaciones de Santiago, 10 de enero de 2008, No LegalPublishing 38166.

Cecinas La Preferida S.A. con sociedad Comercial Salinak Limitada (2005), Corte Suprema, 27 de julio de 2005 (Resolución de contrato. Indemnización de perjuicios procedente. Entrega de producto distinto al convenido. Compraventa), cita Westlaw/3930/2005

Comercial Automotriz Quilín Limitada contra Ide Sanzberro, Julián (2009), Corte Suprema, 18 de noviembre de 2009 (resolución de contrato), cita Westlaw CL/JUR/3630/2009.

Consorcio de Trasportes Trancura Limitada contra Tocale Tuna, Romilio Perfecto (2010), Corte Suprema, 19 de enero de 2010 (Contrato de compraventa contiene error sustancial si este trata sobre el año de fabricación del producto adquirido) cita Westlaw CL/ JUR/815/2010.

Fernando Alejandro Vega Ríos c. Sociedad Codimar Limitada (2003) Juzgado Civil de Antofagasta, 28 de marzo de 2002 (Resolución de contato de compraventa de vehículo motorizado), cita Westlaw: CL/JUR/540/2002.

Flores Marta con Pérez Eulogio (1988), Corte de Apelaciones de Santiago, 10 de marzo de 1988 (vicios redhibitorios, acción de nulidad, rescisión del contrato) Id., Microjuris MJJ3765.

Henríquez Durán, Carlos y otro (2007), Corte de Apelaciones de Rancagua, 4 de septiembre de 2007 (incumplimiento de contrato), Id. Microjuris MJJ15490.

José Hilario Arriagada Sepúlveda; con Ricardo Fernández Toloza (2002), Corte de Apelaciones de Concepción, 9 de enero de 2002 (contrato de compraventa, resolución) CL/ JUR/1335/2002.

Mario Enrique Villagrán Medina con Guillermo Hernán Godoy Fernández; Sergio Villagrán Medinala (2006), Corte Suprema, 15 de mayo de 2006 (Causa y Objeto en la Venta de Cosa Ajena. Inoponibilidad), cita Westlaw CL/JUR/7608/2006.

Mario Jara Carrasco y otros con San Francisco Limitada (2006), Corte de Apelaciones de San Miguel, 27 de enero de 2006 (vicios redhibitorios prescripción acción indemnizatoria) cita Westlaw CL/JUR/8696/2006.

Medina Rojas, Alejandro E. con Natural Home S.A. (2001), Corte de Apelaciones de Santiago, 5 de septiembre de 2001 (condición resolutoria tácita), Id. Microjuris MJJ7259.

Muñoz Carvajal Carmen c. Inversiones e Inmobiliaria Las Nieves (2011) Corte Suprema, 18 de mayo de 2011 (Publicidad efectuada para la venta al público de departamentos forma parte del contrato de compraventa celebrado con posterioridad) cita Westlaw CL/ JUR/4279/2011.

Nieves Rodríguez Cañas; con Juan Espinola Prieto (1990) Corte de Apelaciones de Santiago, 6 de junio de 1990 (Acciones Sociedad Anónima. Normas Aplicables a la Transferencia. 
Traspaso Imperfecto Produce Incumplimiento de la Obligación de Entrega por Parte del Vendedor. Condición Resolutoria Tácita), cita Westlaw CL/JUR/352/1990.

Rosario Larzabal Beraza con Sociedad Inmobiliaria Talasia Limitada (2008), Corte Suprema,

27 de marzo de 2008 (vicios redhibitorios, prescripción acción indemnizatoria), cita Westlaw CL/JUR/7324/2008.

Silva Escandón María Gabriela contra Dosque Contreras María Luisa (1993), Corte de Apelaciones de Concepción, 1 de diciembre de 2033 (Compraventa. Obligaciones del vendedor. Saneamiento de la evicción. Tradición. Embargo) cita Westlaw Chile: CL/ JUR/66/1993.

Sin identificación de partes (1990) Corte de Apelaciones de Santiago (falta de entrega y resolución) 31 de julio de 1990, cita Westlaw: CL/JUR/356/1990.

Supermercado de Materiales de la Construcción Limitada contra Empresa Constructora de Viviendas Económicas Diez, Luengo, Weil (2010), Corte Suprema, 27 de mayo de 2010 (Acciones propias de los vicios redhibitorios no exigen ni culpa ni dolo por parte del vendedor de la cosa), cita Westlaw: CL/JUR/3822/2010.

Toro Mancilla, Rodrigo cl Banco Santander (2009), Corte de Apelaciones de Valdivia, 16 de noviembre de 2009 (Indemnización de perjuicios) Id., Microjuris 22361. 